\title{
Geroprotectors and Skeletal Health: Beyond the Headlines
}

\author{
Alexandra Rayson ${ }^{1}$, Maya Boudiffa ${ }^{1}$, Maneeha Naveed $^{1}$, Jon Griffin ${ }^{2}$, Enrico Dall'Ara $^{1,3}$ and \\ llaria Bellantuono ${ }^{1 *}$ \\ ${ }^{1}$ Healthy Lifespan Institute, Department of Oncology and Metabolism, The Medical School, Sheffield, United Kingdom, ${ }^{2}$ Healthy \\ Lifespan Institute, Department of Molecular Biology and Biotechnology, The University of Sheffield, Sheffield, United Kingdom, \\ ${ }^{3}$ Insigneo Institute for in silico Medicine, Sheffield, United Kingdom
}

\section{OPEN ACCESS}

Edited by: Elizabeth Lara Ostler, University of Brighton, United Kingdom

Reviewed by: loannis Kanakis, University of Chester, United Kingdom Alexey Moskalev, Komi Scientific Center (RAS), Russia

${ }^{*}$ Correspondence: llaria Bellantuono I.bellantuono@sheffield.ac.uk

Specialty section:

This article was submitted to Cell Growth and Division, a section of the journal Frontiers in Cell and Developmental Biology

Received: 17 March 2021 Accepted: 10 January 2022 Published: 09 February 2022

Citation: Rayson A, Boudiffa M, Naveed M, Griffin J, Dall'Ara E and Bellantuono I (2022) Geroprotectors and Skeletal Health: Beyond the Headlines. Front. Cell Dev. Biol. 10:682045. doi: 10.3389/fcell.2022.682045
Osteoporosis and osteoarthritis are the most common age-related diseases of the musculoskeletal system. They are responsible for high level of healthcare use and are often associated with comorbidities. Mechanisms of ageing such as senescence, inflammation and autophagy are common drivers for both diseases and molecules targeting those mechanisms (geroprotectors) have potential to prevent both diseases and their co-morbidities. However, studies to test the efficacy of geroprotectors on bone and joints are scant. The limited studies available show promising results to prevent and reverse Osteoporosis-like disease. In contrast, the effects on the development of Osteoarthritis-like disease in ageing mice has been disappointing thus far. Here we review the literature and report novel data on the effect of geroprotectors for Osteoporosis and Osteoarthritis, we challenge the notion that extension of lifespan correlates with extension of healthspan in all tissues and we highlight the need for more thorough studies to test the effects of geroprotectors on skeletal health in ageing organisms.

Keywords: aging, senescence, osteoarthritis, osteoporosis, geroprotectors, mouse models

\section{INTRODUCTION}

In the United Kingdom, musculoskeletal disorders are responsible for approximately one third of General Practitioner consultations and for a NHS budget of nearly $£ 5$ billions/annum (Executive, 2015). In addition, an estimated 8.9 million working days were lost in 2020 for musculoskeletal disorders, accounting for $34 \%$ of all working days lost due to ill-health in the United Kingdom alone (Health and Safety Executive, 2020). As a whole, musculoskeletal disorders cause more functional limitations in the adult population in the western world than any other group of disorders (Woolf and Pfleger, 2003).

The two most frequent musculoskeletal diseases are osteoarthritis $(\mathrm{OA})$ and osteoporosis $(\mathrm{OP})$. $\mathrm{OA}$, the most common age-related joint pathology, is characterized by cartilage degradation and inflammation in the joint, thickening of the bone plate, changes in subchondral bone and formation of osteophytes (Lotz and Caramés, 2011). Symptomatic knee OA occurs in 10\% of men and 13\% of women aged 60 years or older (Zhang and Jordan, 2010). The number of people affected with symptomatic $\mathrm{OA}$ is likely to increase due to the aging of the population and the obesity epidemic, an important risk factor driving OA (Raud et al., 2020). Patients with OA have higher levels of comorbidity compared to those of similar age without OA (Kadam et al., 2004). OA is significantly associated with other musculoskeletal diseases such as other arthropathies, synovial and tendon disorders and non-musculoskeletal comorbidities such as gastritis, intestinal diverticula and 
ischemic heart disease (Kadam et al., 2004). There is no effective cure for OA. Current management of OA is limited to symptoms' alleviation (Bijlsma et al., 2011) followed by joint replacement when pharmacological management of the pain is no longer effective.

OP is characterised by significant bone loss and increased risk of fractures. Osteoporosis is defined by the World Health Organization when the mineral bone density of a person is 2.5 standard deviations below the young normal mean. It is most frequent in post-menopausal women and it affects around one in five men and one in two women over the age of 50 (Poole and Compston, 2006). Although present drugs reduce the risk of fractures, the number needed to treat (i.e., the number of patients that need to be treated for one to benefit compared with a control in a clinical trial) to prevent a fracture is $>50$ over $1-3$ year period (Crandall et al., 2014), suggesting the need to find new more effective interventions for OP. Furthermore, 92\% of patients affected with osteoporosis present other age-related comorbidities that can include cardiovascular, neurological and gastric conditions (Salive, 2013).

The frequent association of both OP and OA with comorbidities often results in problems of polypharmacy, including increased adverse events and reduced efficacy of their treatments due to drug-drug interaction or disease-drug interactions (Van Der Heide et al., 2018). Up until now, research has focused predominantly on the identification of drugs for the maintenance of function of single tissues (i.e., bone or cartilage) or the identification of treatments for individual musculoskeletal diseases. However, as both conditions are associated with high level of comorbidities and polypharmacy, this approach is ineffective (Tinetti et al., 2012) and approaches which target clusters of diseases would be an advantage.

\section{Osteoarthritis and Ageing}

The onset of $\mathrm{OA}$ is characterised by alteration in the extracellular matrix (ECM) produced by chondrocytes, which stimulates their increased proliferative response, in an attempt to restore articular cartilage (Goldring, 2000). This leads to formation of chondrocyte clusters and increased synthesis of irregular matrix components such as proteoglycans and collagen (Rothwell and Bentley, 1973). With advancing age and OA progression chondrocytes show hallmarks of ageing, such as mitochondrial dysfunction and increased oxidative stress, senescence and inflammation (Loeser et al., 2002; Grishko et al., 2009; Goldring and Otero, 2011; Loeser et al., 2016) as well as aging associated changes in autophagy (Caramés et al., 2010). This results in a reduced ability to produce ECM and an increase in catabolic processes largely mediated by proinflammatory cytokines and mediators such as metalloproteinases (Burrage et al., 2006). In turn, the ECM becomes more vulnerable to damage, leading to the onset of $\mathrm{OA}$, increased cartilage degradation and disease progression. The importance of ageing in driving the disease is highlighted by the fact that aged mice show signs of cartilage degradation and develop the full osteoarthritis phenotype faster and more aggressively than young mice after destabilization of the medial meniscus or following injury (Huang et al., 2017).
Therefore, targeting mechanisms of ageing may offer new opportunities for treatment for OA.

\section{Osteoporosis and Ageing}

The adult skeleton is continuously remodelled by osteoclasts, which resorb bone, osteoblasts, which form new bone and osteocytes. Osteocytes derives from osteoblasts and are contained in the bone matrix. Through secreted factors they coordinate the activity of osteoclasts and osteoblasts in response to physical and hormonal stimuli. Osteocytes, Osteoblasts and their precursors secrete RANK-L which binds to RANK (receptor activator of nuclear factor $\kappa-\mathrm{B}$ ) receptor on osteoclasts precursors, initiating their proliferation and differentiation to mature osteoclasts able to resorb bone. Osteoclast activation is inhibited by another protein known as osteoprotegerin (OPG) produced by osteocytes and osteoblasts, which acts as a decoy RANK-L and therefore competes with RANK-L for receptors. Although RANK-L and macrophage colony stimulating factor (M-CSF) are essential for osteoclastogenesis, additional cytokines such as TNF-alpha and IL-1 are likely to contribute to the regulation of osteoclast formation both in physiological and pathological condition such as oestrogen deficiency in postmenopausal women. Features of bone ageing include reduction in bone mass and bone mineral content, changes in bone shape and structure with loss of trabecular bone, thinning of cortical bone and increased porosity, enlargement of the medullary cavity, higher levels of bone marrow fat, and increase in bone turnover (Pignolo et al., 2019). At the cellular level, there is an increase in osteoclast resorption and a decrease in osteoblast bone formation, leading to a reduction in bone density and increased risk of fracture. Increased age has long been associated with reduced bone mass, which is largely thought to be due to hormonal deficiency, mainly oestrogen due to menopause. However, age-associated bone loss occurs even in individuals with normal levels of sex steroids (Riggs et al., 2008) and there is a close association between the effects of loss of oestrogen and dysregulation of mechanisms driving ageing. Similarly, to OA dysregulation of mechanisms of ageing such as inflammation, autophagy, increased oxidative stress and senescence have also been associated with OP (Farr and Khosla, 2019; Yin et al., 2019). Some of these mechanisms have been shown to be deficient in presence of decreased oestrogen. In an ovariectomised rat model, a significant reduction in levels of autophagy in osteocytes correlated with an increase in oxidative stress and bone loss (Yang et al., 2014). In addition, ovariectomy (OVX) resulted in significant acceleration of the epigenetic clock, the DNA methylation changes occurring with age (Stubbs et al., 2017) suggesting a close link between oestrogen deficiency and ageing, the two main drivers of OP. Therefore, ways to target mechanisms of ageing may offer new opportunities for the development of improved treatment in OP.

\section{GEROPROTECTORS}

Recent work has shown that it is possible to prevent or even reverse the dysregulation of oxidative stress, autophagy and the 
occurrence of senescence using a new class of drugs called geroprotectors. Geroprotectors are drugs that delay or reverse ageing processes and in doing so target the major risk factors for age-related diseases. They promise to promote health span of more than one organ system at the same time in animal models (Figueira et al., 2016; Bellantuono, 2018). Studies in model organisms or retrospective studies in patients show that they can ameliorate tissue dysfunction and reduce the onset and severity of many diseases [reviewed in (Morsli and Bellantuono, 2021)]. Over 200 compounds have been classified as geroprotectors, each reported to slow ageing and/or extend lifespan in a variety of organisms (geroprotectors.org).

Such drugs could have distinct advantages over present treatments in OP and offer new opportunities for OA due to the fact that they may be able to prevent both OP and OA and their co-morbidities. However, the effects of geroprotectors on skeletal health have received little attention compared to other organ systems with the assumption that these drugs will work equally well for all tissues. Here we review the evidence available to address whether geroprotectors have potential for the care of skeletal age-related diseases and their co-morbidities. We focus on drugs with a good safety profile, which have been shown to target ageing pathways, extend the lifespan and healthspan in animal models and have some evidence of improving health in humans by demonstrating protection from multiple-age-related diseases (Partridge et al., 2020) and for which there are well designed studies in animal models of OP and OA or clinical data available.

Among the most studied geroprotector is Rapamycin. It is an inhibitor of the mTOR signalling pathway, a nutrient sensing pathway closely associated with ageing and longevity (Johnson et al., 2013; Saxton and Sabatini, 2017). mTOR is a highly conserved biological pathway, encompassing two distinct complexes mTORC1 and mTORC2. The two complexes differ in composition and function, with mTORC1 having Raptor and mTORC2 containing Rictor (Saxton and Sabatini, 2017). mTORC1 is acutely inhibited by Rapamycin, whereas mTORC2 requires chronic exposure to be affected (Li et al., 2014). It targets multiple mechanisms of ageing including autophagy, oxidative stress, DNA repair (Li et al., 2014; Figueira et al., 2016). More recently Rapamycin has also been shown to inhibit the Senescence Associated Secretory Phenotype (SASP) (Wang et al., 2017), composed of pro-inflammatory and tissue remodelling factors and secreted by senescent cells. Already in clinical use as an immunosuppressor, Rapamycin has been tested extensively in animal models of ageing and age-related diseases [reviewed in (Morsli and Bellantuono, 2021)]. An analogue of Rapamycin, RAD001, has been tested in clinical trials at a substantially lower dose to elicit geroprotective effects to delay immunosenescence with excellent tolerability (Mannick et al., 2014; Mannick et al., 2018).

Metformin, used in the treatment of type 2 diabetes (T2D) (Bosi, 2009; Aroda et al., 2017), has also been extensively investigated for its additional mechanisms of action related to ageing (Valencia et al., 2017; Kulkarni et al., 2020). This includes inhibition of inflammation, reduction in DNA damage and inhibition of SASP (Algire et al., 2012; Moiseeva et al., 2013;
Ashabi et al., 2015). There are multiple evidence in animal models and retrospective human studies that metformin has positive effects on multiple age-related diseases [reviewed in (Morsli and Bellantuono, 2021)]. Indeed a clinical trial, using Metformin to extend survival and reduce the incidence of multiple diseases (the TAME study) has obtained FDA approval (Barzilai et al., 2016).

Less studied but interesting in the context of OA is Acarbose (ACA), an intestinal $\alpha$-glucosidase inhibitor, FDA-approved to treat diabetes and acts by inhibiting digestion of complex carbohydrates and reducing postprandial hyperglycaemia (Dinicolantonio et al., 2015). The mechanisms by which ACA leads to lifespan extension are not well understood. It is considered a calorie restriction mimetic and it has been reported to improve parameters of health, including reduced incidence of lung tumours in males mice, reduced liver degeneration in both sexes and glomerulosclerosis in female mice (Harrison et al., 2019), improved neuromuscular function in females, balance/coordination and grip strength in both sexes (Herrera et al., 2020). Age-related cardiac hypertrophy was seen only in male mice, and this male-specific ageing effect was attenuated by ACA (Herrera et al., 2020).

Similarly, less known but tested in the context of OA is $17 \alpha-$ estradiol (17 $\alpha$-E2), a naturally occurring enantiomer of $17 \beta$ estradiol (17 $\beta$-E2), yet appears to be non-feminizing due to minimal activation of classical oestrogen receptors, ERa and $\operatorname{ER} \beta$ (Stout et al., 2016). It has been shown to extend lifespan in male mice (Harrison et al., 2014), ameliorate age-associated metabolic and inflammatory dysfunction (Stout et al., 2017) and improve male glucose tolerance across much of adult life (Garratt et al., 2017). When administered in later life it maintains body weight, with larger muscle mass and fibres, increased grip strength and coordination (Garratt et al., 2019). The metabolic improvements are sex-specific and influenced by gonadal hormones (Garratt et al., 2017). Little is known on the molecular basis of $17 \alpha-E 2$ on lifespan and healthspan. The metabolic improvements appear to be associated with enhanced hepatic mTORC2 signalling, increased AKT activity and phosphorylation of FOXO1 (Garratt et al., 2017), increased AMPKa and reduced mTOR complex 1 activity in visceral adipose tissue (Stout et al., 2017). These latter changes were not found in liver or quadriceps muscle (Stout et al., 2017).

Of interest, particularly in the context of OA, is Glucosamine (GluN), an amino-monosaccharide derived principally from chitin, a compound found in the exoskeleton of marine invertebrate. It is a component of glycoproteins, proteoglycans and glycosaminoglycans. The main compounds containing GluN are glucosamine hydrochloride, glucosamine sulphate, N-Acetylglucosamine (GlcNAc). Those compounds have different phamarcokinetic and pharmacodynamics and seem to act through different mechanisms, which may account in part for the heterogeneity of response observed in the different studies. For example glucosamine sulphate requires a stabiliser in the form of salt and is therefore less pure than glucosamine hydrochloride, necessitating higher dosage (Owens et al., 2004). Glucosamine (sulphate/hydrochloride) have been shown to extend lifespan in C. Elegans and in ageing mice by mimicking similar effects to a low carbohydrate diet. Indeed, it has been 
shown to activate AMPK, which in turn promotes mitochondrial biogenesis, increase aminoacid transport and inhibits glycolysis (Weimer et al., 2014). GlcNAc has also been seen to promote lifespan extension in C. Elegans but by promoting proteasome activity and autophagy (Denzel et al., 2014). Treatment with GlcNAc showed an increase in mobility function in models of Parkinson's and Alzhemer's disease, suggesting effects on healthspan as well (Denzel et al., 2014). In addition, examination of abitual use of glucosamine supplements in a retrospective study showed a lower incidence of coronary heart disease and stroke (Ma et al., 2019), and a reduction in mortality due to cancer, respiratory, digestive and cardiovascular diseases (Li Z.-H. et al., 2020). However, glucosamine users were also more active and often took additional supplements compared to the control group, making it difficult to assess whether these effects were due to GluN uptake per se. GluN has been shown to have a good safety profile and may have promise as geroprotector (Zeng et al., 2015) but well controlled prospective preclinical and clinical studies with long duration are required to assess whether any of the GluN compounds improves health span safely.

Spermidine is also emerging for its geroprotective properties. It is a naturally occurring polyamine, and its concentration has been shown to decline with age in both males and females rat tissues and in erythrocytes (Jänne et al., 1964). Administration of spermidine extends lifespan in aged cells, C. Elegans, Drosophila (Eisenberg et al., 2009) and mice (Eisenberg et al., 2016) and it has been shown to improve some parameters of health. It increase B cell function in aged mice and humans (Zhang et al., 2019), cardiac function and arterial stiffness in aged mice (Eisenberg et al., 2016) and synapse ageing in drosophila (Maglione et al., 2019). Dhal salt sensitive rats fed high salt diet receiving spermidine showed reduced high blood pressure, delayed progression of heart failure and renal abnormalities seen in presence of hypertension (Eisenberg et al., 2016). In addition, administration of spermidine reduced the severity of liver lesions in a mouse model of liver cirrhosis (Yue et al., 2017) and of retinal ganglion cell death in a mouse model of optic nerve injury (Noro et al., 2015). In a community-based cohort study participants taking spermidine showed significant lower all-cause mortality (Kiechl et al., 2018). These effects seem to be the result of increased autophagy, mitophagy and mitochondrial biogenesis (Eisenberg et al., 2016). However, changes in other mechanisms associated with ageing have also been seen in presence of spermidine supplementation such as decreased histon $\mathrm{H} 3$ acetylation with possible consequences for gene expression (Eisenberg et al., 2009). Safety profile will require appropriate assessment in prospective studies as the results in animal models have been obtained using a wide range of doses, some of which may show toxicity when translating into humans.

Senolytics [reviewed in (Kirkland and Tchkonia, 2020)] are among the most promising geroprotectors due to their intermittent mode of administration to periodically eliminate newly formed senescent cells. This has the potential to reduce side effects and be more cost-effective. Senescent cells are characterised by irreversible cell cycle arrest and the presence of SASP. They accumulate with age and they have been shown to be causal to multiple age-associated tissue dysfunction or agerelated diseases in animal models (Jeyapalan et al., 2007; Wang et al., 2009). Senolytics work by targeting specific survival pathway and selectively inducing senescent cell death (Kirkland et al., 2017). The senolytics Dasatinib, a tyrosine kinase inhibitor, and Navitoclax, a BCL2 family inhibitor, are among those most studied. They both have anti-neoplastic activity and side effects include increased risk of bleeding, immunosuppression and increased risk of infections (Wilson et al., 2010; Futosi et al., 2012; Rodriguez et al., 2012). Dasatinib has little or no senolytic activity on its own but has senolytic activity only when given in combination with Quercetin (Zhu et al., 2015). Quercetin and Fisetin (another senolytic) are flavonoids found in plants and fruits and sold as food supplements for their antioxidant activities with a good safety profile. The dose required to elicit senolytic activity is higher than that which is recommended as a food supplement and appropriate long-term safety studies are required. Several clinical trials with these drugs are ongoing.

\section{Geroprotectors to Target OA}

In vitro studies on the effects of geroprotectors are limited. Rapamycin has been found to modulate chondrocytes' survival, cell death and senescence [reviewed in ( $\mathrm{Pal}$ et al., 2015)]. In addition, it has been shown to increase expression of autophagy genes in human and mouse chondrocytes (Zhang et al., 2015) and in bovine cartilage explants (Caramés et al., 2012 b). This increase was associated with an increased expression of two major proteins of the cartilage matrix, aggrecan and type II collagene, and a decreased expression of metalloproteinases and chemokines (Zhang et al., 2015). Similarly, metformin has been shown to increase chondrocyte survival and delay senescence by increasing AMPK and reducing TORC1 signalling (Feng et al., 2020) resulting in attenuated aggrecanase activity and proteoglycan breakdown in chondrocytes grown in presence of inflammatory cytokines (Li H. et al., 2020). Senolytics Navitoclax, Fisetin and UBX0101 showed a reduction in markers of inflammation, an increase in markers of matrix deposition (e.g., glycosaminoglycans) (Jeon et al., 2017; Zheng et al., 2017; Yang et al., 2020) and an improvement in chondrocytes proliferation (Jeon et al., 2017) in human OA chondrocytes. Glucosamine has been shown to have anabolic effects by inducing the production of hyaluronic acid in human chondrocytes and synovial cells and regulate expression of inflammatory cytokines. A summary of the key in vitro studies is here (Henrotin et al., 2012). Spermidine has only recently been studied in the context of OA. In vitro it shows chondro-protective effects from oxidative damage and cell death, and antiinflammatory properties (Silvestri et al., 2018; D'adamo et al., 2020).

In vivo most studies testing geroprotectors to delay or reverse the onset of OA are mainly performed in rodent models at young age following induction of $\mathrm{OA}$ by destabilization of the meniscus (Table 1). Administration of Rapamycin for 10 weeks at $1 \mathrm{mg} / \mathrm{kg} /$ day after transection of the medial meniscal tibial ligament and the medial collateral ligament in 8 weeks old mice decreased cartilage degradation (Caramés et al., 2012a). Similarly, intra- 
TABLE 1 | Summary of studies testing geroprotectors to attenuate OA in experimental models and patients.

Geroprotector

Model

Age at the start

of the experiment

Rapamycin $1 \mathrm{mg} / \mathrm{kg} /$ day i.p. Starting at the time of MMTL + MCL

Rapamycin ( $10 \mu \mathrm{l}$ of $10 \mu \mathrm{M}$ solution) $2 \times$ / week intra-articular injection starting at the time of DMM

\begin{tabular}{|c|c|c|c|c|}
\hline $\begin{array}{l}\text { Rapamycin }\left(100 \mathrm{ng}^{-1} \mu \mathrm{g}\right) \text { intra-articular } \\
\text { gelatin hydrogel starting at the time of DMM }\end{array}$ & Mice C57BI/6-DMM & 8 weeks & $\downarrow$ Cartilage loss & Matsuzaki et al. (2014) \\
\hline Rapamycin14 mg/kg/day & Mice UM-HET & $\begin{array}{l}\text { Assessed at natural } \\
\text { death }\end{array}$ & No difference in OA score & Ewart et al. (2020) \\
\hline Acarbose $1,000 \mathrm{mg} / \mathrm{kg} / \mathrm{day}$ & Mice UM-HET & $\begin{array}{l}\text { Assessed at natural } \\
\text { death }\end{array}$ & No difference in OA score & Ewart et al. (2020) \\
\hline 17-a-estradiol $14.4 \mathrm{mg} / \mathrm{kg} /$ day & Mice UM-HET & $\begin{array}{l}\text { Assessed at natural } \\
\text { death }\end{array}$ & No difference in OA score & Ewart et al. (2020) \\
\hline $\begin{array}{l}\text { Metformin } \\
\text { Intra-gastric } 200 \mathrm{mg} / \mathrm{kg} / \text { day starting } \\
3 \text { days post-DMM } \\
\text { Intra-articular } 0.1 \mathrm{mmol} / \mathrm{kg} \text { twice/week } \\
\text { post-DMM }\end{array}$ & Mice C57BI/6-DMM & 8-10 weeks & $\begin{array}{l}\downarrow \text { Cartilage loss. } \uparrow \text { paw } \\
\text { withdrawal threshold } \downarrow \text { weight- } \\
\text { bearing asymmetry }\end{array}$ & Li et al. (2020a) \\
\hline $\begin{array}{l}\text { Metformin } 205 \mathrm{mg} / \mathrm{kg} / \text { day in drinking water } \\
2 \text { weeks prior to DMM } \\
2 \text { weeks post-DMM }\end{array}$ & Mice C57BI/6-DMM & 10 weeks & $\begin{array}{l}\downarrow \text { Cartilage loss } \\
\downarrow \text { Synovitis } \\
\downarrow \text { Osteophytes } \\
\text { No effect on subchondral bone } \\
\text { mass } \\
\text { †paw withdrawal threshold } \\
\uparrow \text { spontanous activity }\end{array}$ & Li et al. (2020b) \\
\hline $\begin{array}{l}\text { Metformin } 51.7 \mathrm{mg} / \mathrm{kg} / \text { day in drinking } \\
\text { water } 1 \text { month post-PMM }\end{array}$ & Rhesus macaques-PMM & $8.5-11.5$ years & $\begin{array}{l}\downarrow \text { Cartilage loss } \\
\downarrow \text { subchondral bone mass } \\
\uparrow \text { standing and walking time }\end{array}$ & Li et al. (2020b) \\
\hline $\begin{array}{l}\text { Fisetin } 20 \text { mg/kg/day gavage immediately } \\
\text { after DMM }\end{array}$ & Mice C57BI/6-DMM & 10 weeks & $\begin{array}{l}\downarrow \text { Cartilage loss } \\
\downarrow \text { subchondral bone mass } \\
\downarrow \text { Synovitis }\end{array}$ & Zheng et al. (2017) \\
\hline $\begin{array}{l}\text { Navitoclax } 0.25,1,5 \mu \mathrm{M} \text { intra-articular } \\
\text { injection at the time of DMM twice/week for } \\
2 \text { weeks }\end{array}$ & SD Rat-DMM & 4-6 weeks & $\begin{array}{l}\downarrow \text { Cartilage loss } \\
\downarrow \text { subchondral bone mass } \\
\downarrow \text { osteophytes }\end{array}$ & Yang et al. (2020) \\
\hline $\begin{array}{l}\text { UBX0101 intra-articular }(10 \mu \mathrm{l} \text { of } \\
0.2-5 \mathrm{mM}) \\
14 \text { days post-ACLT } \\
42 \text { days post-ACLT }\end{array}$ & Mice C57BI/6-ACLT & 10 weeks & $\begin{array}{l}\downarrow \text { Cartilage loss } \\
\downarrow \text { subchondral bone mass } \\
\downarrow \text { Pain } \\
\text { \osteophytes (only with } \\
\text { d14 post-ACLT treatment) }\end{array}$ & Jeon et al. (2017) \\
\hline $\begin{array}{l}\text { UBX0101 intra-articular ( } 10 \mu \mathrm{l} \text { of } 1 \mathrm{mM}) \\
2 \text { weeks post-ACLT }\end{array}$ & Mice C57BI/6-ACLT & 19 months & $\begin{array}{l}\downarrow \text { Pain } \\
\text { No change in cartilage loss, } \\
\text { subchondral bone mass }\end{array}$ & Jeon et al. (2017) \\
\hline UBX0101 intra-articular & $\begin{array}{l}\text { Phase II clinical trial-OA } \\
\text { patients }\end{array}$ & $\mathrm{N} / \mathrm{A}$ & No difference in pain & Inc, (2020) \\
\hline $\begin{array}{l}\text { Glucosamine Sulphate oral } 250 \mathrm{mg} / \mathrm{kg} / \text { day } \\
\text { starting at } 5 \text { weeks post ACLT for } 10 \text { days }\end{array}$ & Wistar Rats ACLT & $\mathrm{N} / \mathrm{A}$ & $\begin{array}{l}\downarrow \text { Pain } \\
\downarrow \text { Cartilage loss }\end{array}$ & Wen et al. (2010) \\
\hline $\begin{array}{l}\text { Glucosamine Hydrochloride oral (approx. } \\
1,000 \mathrm{mg} / \mathrm{kg} / \text { day) for } 8 \text { weeks }\end{array}$ & Wistar Rats ACLT & 10 weeks & $\begin{array}{l}\downarrow \text { Cartilage loss } \\
\downarrow \text { Bone erosion }\end{array}$ & Naito et al. (2010) \\
\hline Glucosamine & $\begin{array}{l}\text { Systematic review and } \\
\text { meta-analysis of clinical } \\
\text { trials }\end{array}$ & $\begin{array}{l}\text { Approx. } 40-70 \text { years } \\
\text { old (when available) }\end{array}$ & $\begin{array}{l}\text { No difference observed on } \\
\text { pain scores }\end{array}$ & $\begin{array}{l}\text { (Liu et al., 2018) (Runhaar et al., } \\
\text { 2017) (Zhu et al., 2018) (Wandel } \\
\text { et al., 2010) }\end{array}$ \\
\hline
\end{tabular}

(Continued on following page) 
TABLE 1 | (Continued) Summary of studies testing geroprotectors to attenuate OA in experimental models and patients.

\begin{tabular}{|c|c|c|c|c|}
\hline Geroprotector & Model & $\begin{array}{l}\text { Age at the start } \\
\text { of the experiment }\end{array}$ & $\begin{array}{l}\text { Key findings (compared } \\
\text { to controls) }\end{array}$ & Reference \\
\hline Glucosamine & $\begin{array}{l}\text { Systematic review and } \\
\text { meta-analysis of clinical } \\
\text { trials }\end{array}$ & $\mathrm{N} / \mathrm{A}$ & $\begin{array}{l}\text { \VAS pain } \\
\text { No effect on WOMAC }\end{array}$ & $\begin{array}{l}\text { (Ogata et al., 2018) } \\
\text { (Simental-Mendía et al., 2018) }\end{array}$ \\
\hline $\begin{array}{l}\text { Spermidine } 0.3-3-6 \mathrm{mM} / \text { day for } \\
4-8 \text { weeks }\end{array}$ & C57BL6 + ACLT & 12 weeks & $\begin{array}{l}\downarrow \text { Cartilage loss } \\
\downarrow \text { Osteophytes (@3-6 mM) } \\
\text { linflammation } \\
\downarrow \text { MMP13 } \\
\uparrow \text { Aggecan/collagenll }\end{array}$ & Chen et al. (2020) \\
\hline
\end{tabular}

MMTL, medial meniscotibial ligament; MCL, medial collateral ligament; DMM, destabilization of the medial meniscus, PMM, partial medial meniscectomy; ACLT, anterior cruciate ligament transection, i.p, Intra-peritoneal; SD, Sprague-Dawley; VAS, Visual Analogue Scale; WOMAC, Western Ontario and McMaster Universities Osteoarthritis Index.

articular administration of rapamycin twice a week for 8 weeks in 10 weeks old mice following destabilization of the medial meniscus (DMM) or injection of hydrogel containing rapamycin in the joint in 8 weeks old DMM mice showed a reduction of OARSI score (Matsuzaki et al., 2014; Takayama et al., 2014). In all these studies rapamycin was given immediately after the DMM and prior to the establishment of damage in young animals. A similar experimental design has been used to test other geroprotectors such as Fisetin, Metformin, Spermidine or Navitoclax with similar results (Zheng et al., 2017; Li J. et al., 2020; Chen et al., 2020; Yang et al., 2020). However, the administration of Metformin (4 mg/day in drinking water, until the animals were sacrificed), was also administered 2 weeks after DMM surgery and caused partial but significant reduction in cartilage degradation, suggesting that Metformin may be beneficial even when given at very early stages of damage (Li J. et al., 2020). This has been confirmed in adult Rhesus Macaques where Metformin was administered 1 month after surgery and significantly alleviated cartilage degradation and subchondral bone thickening with a reduction in pain-related behaviour and improvement in the duration of standing and walking (Li J. et al., 2020). Similarly, testing of glucosamine in young rats showed attenuation of cartilage degradation following transection of the anterior cruciate ligament using either GluN sulphate (Wen et al., 2010) or hydrochloride (Naito et al., 2010) even when given 5 weeks post-induction of $\mathrm{OA}$ at high dose (Naito et al., 2010).

The effects of geroprotectors become less effective when administered in older mice or in young mice when the disease is already well established. Intra-articular treatment with a new senolytic UBX0101 prevented OA disease in young mice. However, administered when OA was established only led to improvement in some aspects of the disease such as cartilage structure and pain, but no rescue of subchondral bone remodelling and osteophyte formation (Jeon et al., 2017). When the disease was triggered in 19-month-old mice administration of the same molecule in advance stages of the disease showed no improvement in cartilage structure despite evidence of senescent cell clearance from the articular cartilage (Jeon et al., 2017). This was associated with a lack of increased expression of prochondrogenic genes, suggesting that there may be an age-related decline in the proliferative capacities of articular chondrocytes and ability to produce matrix with age, impacting further on responses. Similarly a phase I clinical trial with UBX0101 in patients with moderate to severe OA did not show any improvement in pain score used as primary outcome (Inc, 2020).

Similarly little or no response was observed by our group and others when the effect of Acarbose, 17- $\alpha$-estradiol and Rapamycin were assessed in aged UM-HET mice. UM-HET3 are produced by a cross between $(\mathrm{BALB} / \mathrm{cByJ} \times \mathrm{C} 57 \mathrm{BL} / 6 \mathrm{~J}) \mathrm{F} 1$ mothers and $(\mathrm{C} 3 \mathrm{H} / \mathrm{HeJ} \times \mathrm{DBA} / 2 \mathrm{~J}) \mathrm{F} 1$ fathers and have been used at the National Institute on Ageing Intervention Testing Programme (NIA-ITP) (Nadon et al., 2017).

All three compounds have been shown to extend lifespan in these mice, although with some sex differences (Harrison et al., 2009; Miller et al., 2011; Harrison et al., 2014; Miller et al., 2014; Strong et al., 2016; Harrison et al., 2019). Similarly to what reported in the study by (Ewart et al., 2020) our unpublished data showed a significant increase in cartilage degradation with age in these mice in both males and females (Figures 1, 2 and Supplementary Material). However, none of the treatments showed any significant improvement in cartilage degradation measured by OARSI scores in both males and females (Figures 3A-C and Supplementary Material) assessed at 12 and 22 months of age. Treatment started at 4 months of age with the exception of 17- $\alpha$-E2, which started at 10 months of age when the oestrus cycle starts reducing to avoid a potential interference with sexual development (Nelson et al., 1982). Drugs were used at the same concentrations shown to elicit lifespan extension $(1,000$, 14 , and $14.4 \mathrm{mg}$ per $\mathrm{kg}$ of diet for acarbose, rapamycin and 17- $\mathrm{a}-$ E2, respectively). These data are in line with what reported by Ewart et al. (2020) when testing the effect of acarbose and 17- $\alpha$ E2estradiol in the same mice using a different experimental design. In the latter, mice were collected at the time of death, whereas in our experiments the mice were culled at fixed time points, reducing some of the variability that may have arisen with the previous experimental design. It is still possible that our study was underpowered. However, even if this was the case, it indicates that any effect is very small. It is possible that these drugs may work in aged mice only in situation of challenge (e.g., following DMM surgery) and therefore they should be tested in mice following induction of OA disease in older age. 

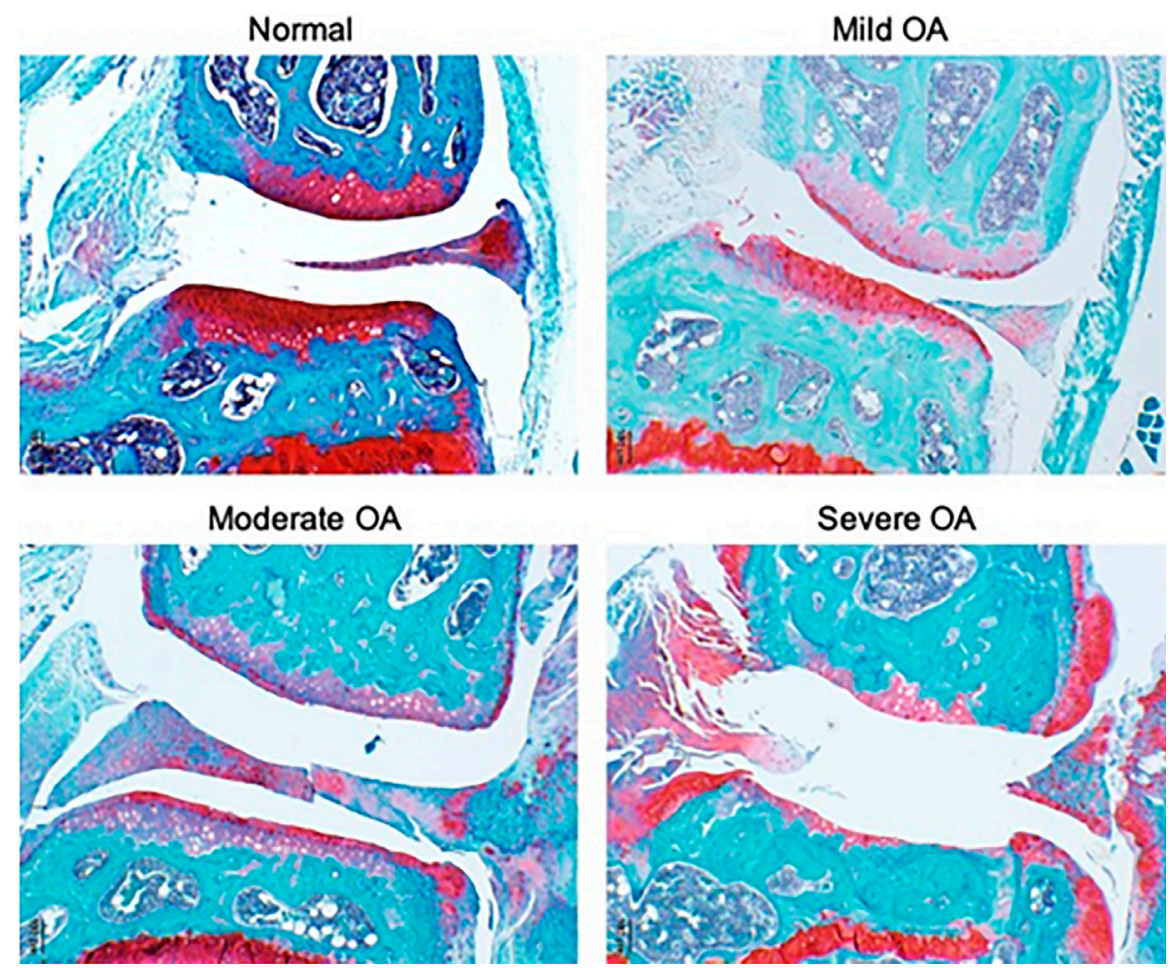

FIGURE 1 | Representative images of joint pathology in UM-HET3 mice. Normal includes joints with an OARSI score of 0-.5, mild 1-2, moderate 3-4 and severe 5-6.

No studies are available to test the effects of Glucosamine in aged animals. However, there is an abundance of studies in patients affected by $\mathrm{OA}$ with very contrasting results as highlighted by meta-analysis and systematic reviews (Wandel et al., 2010; Runhaar et al., 2017; Liu et al., 2018; Ogata et al., 2018; Zhu et al., 2018). The discrepancy seems to lie in whether the trials contained biases (e.g., trials led by industry were more likely to show positive results) (Vlad et al., 2007) or the sample size (trials with over 100 patients seem to show no effect of glucosamine on pain) (Wandel et al., 2010; Runhaar et al., 2017). In addition, the formulation of glucosamine produced by Rottapharm seemed to be the most effective (Towheed et al., 2005; Vlad et al., 2007; Runhaar et al., 2017). However, it is unclear whether this is due to the formulation or to the fact that trials with the Rottapharm formulation targeted patients at early stages of disease. Whilst recent meta-analysis concluded that studies have shown modest or no efficacy of glucosamine on pain or other parameters of OA questions remain whether the treatment should be tested for longer, with a higher dose (Mccarty et al., 2019) and whether patients should be stratified based on severity of the disease and/or age, a factor that is never considered in the analysis.

Overall, these studies highlight that reducing the severity of $\mathrm{OA}$ in older organisms may be challenging and not sufficient on its own. These studies challenge the notion that extension of lifespan can be considered an indirect measure of health span for all tissues. They highlight the need for a comprehensive assessment of the effects of each drugs in all tissues including the skeletal tissues with natural ageing and in models of disease.

\section{Geroprotectors to Target OP}

In vitro studies are primarily focused on the effects of rapamycin on osteoaclasts and osteoblasts. Based on studies using mouse, rabbit and human cells Rapamycin has been shown to reduce osteoclasts' formation, survival and activity (Glantschnig et al., 2003; Kneissel et al., 2004; Browne et al., 2017). Effects on osteoblasts' proliferation, survival and differentiation are inconclusive with differences in reports depending on the dose used and the species from which the cells were derived and whether they were primary or cell lines (Kneissel et al., 2004; Singha et al., 2008; Xian et al., 2012; Huang et al., 2015; Browne et al., 2017; Wu et al., 2019). This is particularly true for its effects on differentiation. For example the analogue of rapamycin Everolimus showed no effect on the osteoblast marker Alkaline phosphatase (ALP) when hMSC were induced to differentiate to the osteoblastic lineage for 7 days at $1 \mathrm{nM}$ but showed a reduction in ALP expression at higher concentration of 10 and $100 \mathrm{nM}$ (Browne et al., 2017). In contrast Runx2 and Osteocalcin, two other markers of osteoblasts differentiation were increased at 1 and $10 \mathrm{nM}$ in the same human osteoblasts cultures but were decreased in murine cultures (Browne et al., 2017). There are many reasons for these discrepancies such as osteoblasts differentiation may proceed at different rates in 

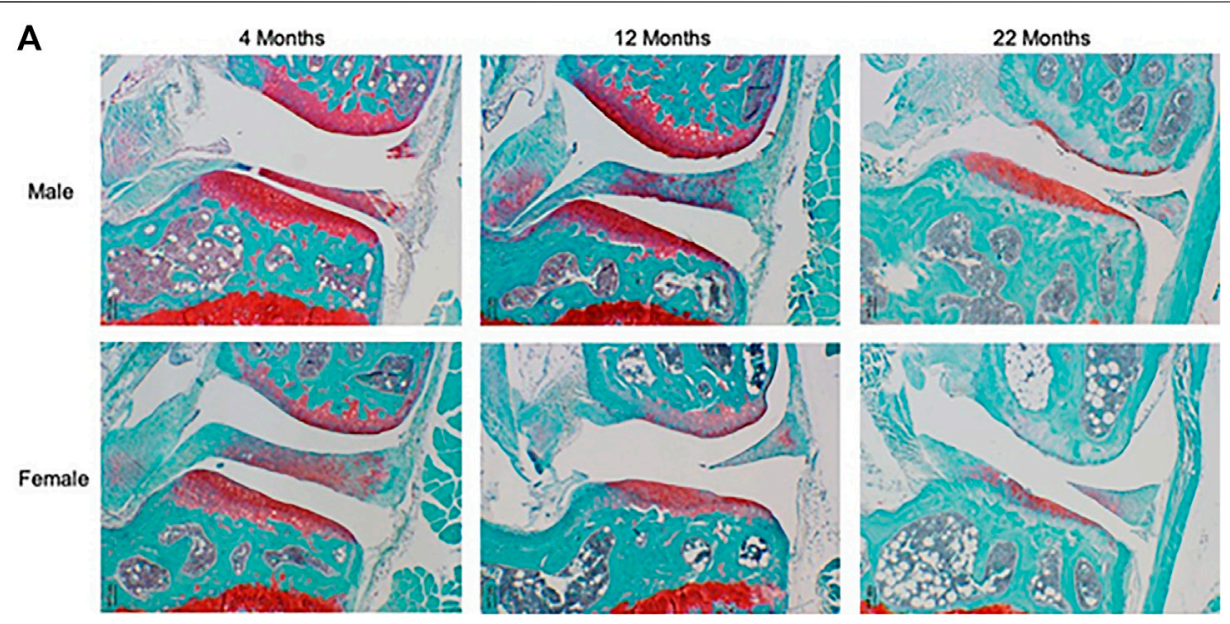

B

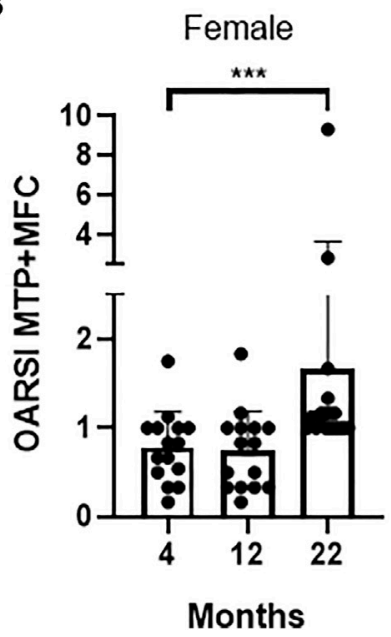

C

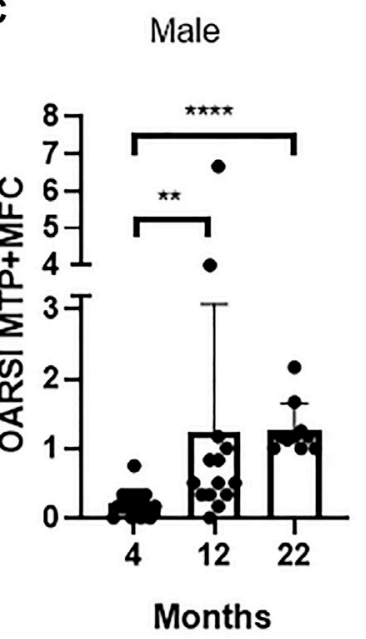

FIGURE 2 | UM-HET3 mice develop joint pathology with age (A) Representative examples of joint pathology in male and female UM-HET3 mice at different ages; (B) Cartilage changes in female mice at 4 months $(n=16), 12$ months $(n=15)$ and 22 months $(n=18)$; (C) Cartilage changes in male mice at $4(n=17)$, 12 ( $n=14)$ and $(n=10) 22$ months. Values are the mean \pm SD of OARSI score for the medial tibia plateau (MTP) plus the medial femoral condyle (MFC). Data were analysed by KruskalWallis test and Dunn's multiple comparisons test, ${ }^{\star \star} p<.01,{ }^{\star \star \star} p<.001,{ }^{\star \star \star \star} p<.0001$.

human, mouse cultures and cell lines and markers of osteoblasts differentiation are dynamic, i.e., they can be upregulated and downregulated at different rates over the period of observation. Assessments of markers over multiple time points may be required to shed some light.

In vitro studies with other geroprotectors are very scant. Fisetin has been shown to inhibit osteoclasts' formation and differentiation but effects on osteoblasts were not reported (Léotoing et al., 2013). Navitoclax reduced senescent cell burden but it also negatively impacted on the number of bone progenitors and osteoblasts in culture inducing apoptosis (Sharma et al., 2020). Spermidine reduced osteoclasts differentiation but did not affect their survival and had no effect on survival and differentiation of osteoblasts (Yamamoto et al., 2012). N-Acetyl glucosamine increased osteoblasts differentiation and mineralization and attenuated the negative effects of hydrogen peroxide on survival and proliferation of osteoblast (Jiang et al., 2018).

Most in vivo studies (summarised in Table 2) have used Rapamycin or one of its derivatives, Everolimus to test their effects on bone loss. Rapamycin and Everolimus have been shown to delay bone loss in mice in situations of challenge, i.e., in models of ovariectomy, iron load, cancer bone disease or ageing (Kneissel et al., 2004; Luo et al., 2016; Browne et al., 2017; Wu et al., 2019). These effects are primarily the result of inhibition of osteoclasts formation and activity with the exception of the study utilising the iron load model where no difference has been observed in the number of osteoclasts but an increase in ALP+ osteoblasts has been reported. A study in 24 months old rats receiving Rapamycin at $1 \mathrm{mg} / \mathrm{kg} /$ day for 12 weeks showed positive effects on osteoblasts activity with an increase in serum osteocalcin and mineral apposition rates (Luo et al., 2016). 


\section{Female}

A
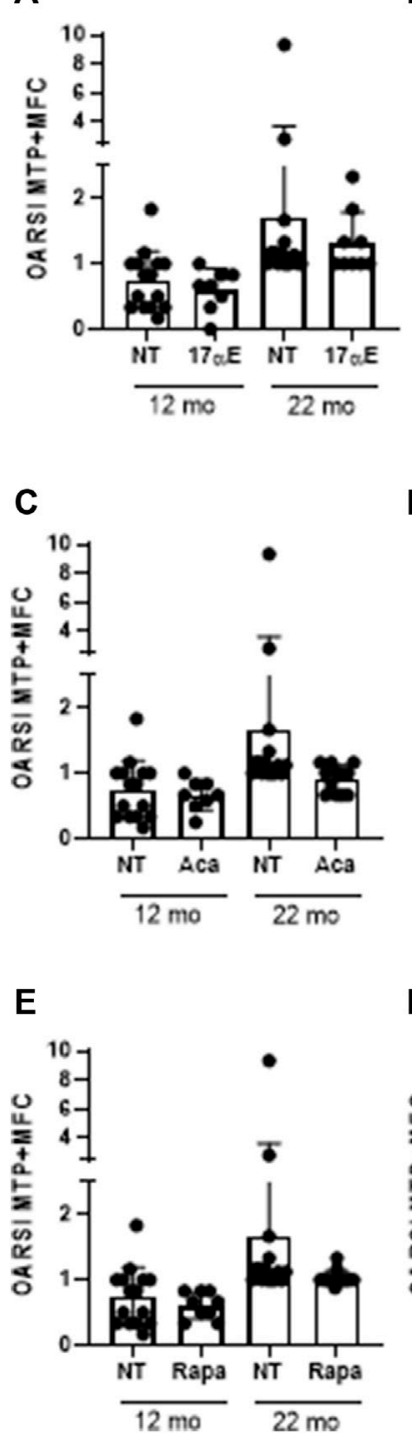

B

Male

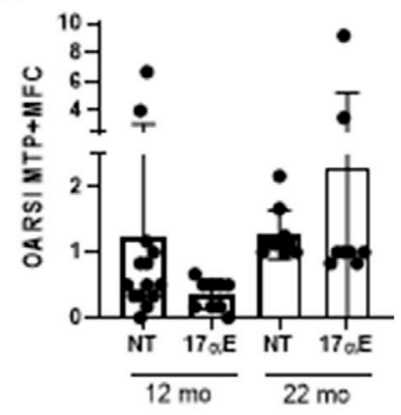

D

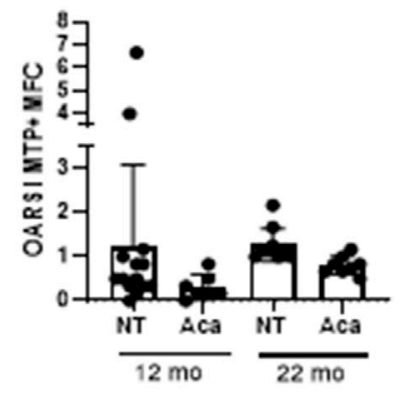

$\mathbf{F}$

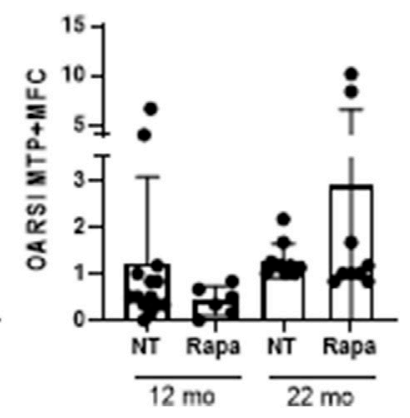

FIGURE 3 | No effect on joint pathology in UMHET3 mice following treatment with 17- $\alpha$-Estradiol, Acarbose and Rapamycin (A) Cartilage changes in female mice at 12 months (NT $n=15 ; 17 \alpha \mathrm{E} n=8$ ) and 22 months (NT $n=18 ; 17 \alpha \mathrm{E} n=9)$ following treatment with 17- $\alpha$-Estradiol (17 $\alpha \mathrm{E})$; (B) Cartilage changes in male mice at 12 months (NT $n=14 ; 17 \mathrm{\alpha E} n=9$ ) and 22 months (NT $n=10,17 \mathrm{\alpha E} n=8$ ) following treatment with $17 \mathrm{aE}$; (C) Cartilage changes in female mice at 12 months (NT $n=15$; ACA $n=8$ ) and 22 months (NT $n=18$; ACA $n=12$ ) following treatment with Acarbose (ACA); (D) Cartilage changes in male mice at 12 months NT $n=14$; ACA $n=$ 7) and 22 months (NT $n=14 ; \mathrm{ACA} n=8$ ) following treatment with ACA; (E) Cartilage changes in female mice at 12 months (NT $n=15$; Rapa $n=8)$ and 22 months (NT $n=$ 18; Rapa $n=12$ ) following treatment with Rapamycin (Rapa); (F) Cartilage changes in male mice at 12 months (NT $n=14$; Rapa $n=6$ ) and 22 months (NT $n=10$; Rapa $n=9$ ) following treatment with Rapamycin (Rapa). Values are the mean \pm SD of OARSI score for the medial tibia plateau (MTP) plus the medial femoral condyle (MFC). Data were analysed by Kruskal-Wallis test and Dunn's multiple comparisons test, ${ }^{\star} p<0.05,{ }^{\star \star} p<0.01,{ }^{\star \star *} p<0.001,{ }^{\star \star \star \star} p<0.0001$. NT, not treated.

The discrepancy in recording positive effects on osteoblasts' activity may be due to the short length of administration of Rapamycin in some of the studies (4-8 weeks). Whilst osteoclasts have shorter lifespan in vivo (2 weeks) osteoblasts turnover takes approximately 3 months (Manolagas, 2000) and therefore it is possible that only those studies assessing osteoblastogenesis for longer periods of time were able to detect an effect.
Of interest is the fact that most studies report outcomes only in trabecular bone and do not assess cortical bone, despite both being important to confer bone strength. Kneissel et al. (2004) (Kneissel et al., 2004) reported a partial protection in trabecular bone but not in cortical bone following treatment of 9 months old rats with Everolimus for $4-8$ weeks at the dose of $3 \mathrm{mg} / \mathrm{kg} /$ day. These data suggest that the effects may be limited to the trabecular bone, the more metabolic active part of the bone. 
TABLE 2 | Summary of in vivo testing of geroprotectors to attenuate bone loss in experimental models.

Geroprotector $\begin{gathered}\text { Model } \\ \begin{array}{c}\text { Age at the start the } \\ \text { experiment }\end{array}\end{gathered}$

Rapamycin

$1 \mathrm{mg} / \mathrm{kg}$ weight/day, i.p. 12 weeks
SD rats
24 months

$\uparrow B M D$

Key findings (compared

Reference

to controls)

$\uparrow$ Trabecular BV/TV and number,

thickness

$\uparrow \mathrm{MAR}$

$\downarrow N$ Oc and serum Tracp 5b

$\uparrow$ serum OCN

Everolimus
$0.5 \mathrm{mg} / \mathrm{kg} /$ day
$1.5 \mathrm{mg} / \mathrm{kg} /$ day
$3.0 \mathrm{mg} / \mathrm{kg} /$ day
Gavage
4-8 weeks treatment

Everolimus i.p

2 days post tumor injection or OVX $1 \mathrm{mg} / \mathrm{kg} /$ day for 4 weeks

Wistar Rats-OVX 9 months

\section{A}

Attenuated cancellous bone loss

$\downarrow$ trabecular number

Kneissel et al.

No effect on cortical bone

$\downarrow N$ Oc

No difference in cancellous bone

formation rates

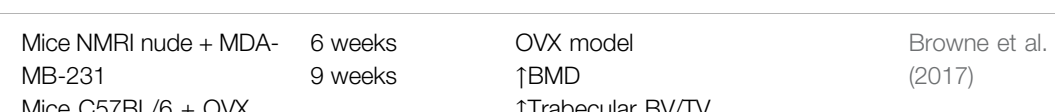

Mice C57BL/6 + OVX $\quad \uparrow$ Trabecular BV/TV

$\downarrow N O c$

Nude tumour model

$\downarrow N$ tumor lesions

$\uparrow B M D$

$\uparrow$ Trabecular BV/TV

$\downarrow N$ Oc

Rapamycin

$3 \mathrm{mg} / \mathrm{kg} /$ day, i.p. for 2 months
Mice Hepcidin knockout 8 weeks

$\mathrm{C} 57 \mathrm{BI} / 6+\mathrm{OVX}$ $\uparrow \mathrm{BMD}$

$\uparrow$ Trabecular BV/TV

No difference in cortical bone

$\uparrow \mathrm{NALP}+\mathrm{Ob}$

No diff in $\mathrm{N} \mathrm{Oc}$

Dasatinib (5 mg/kg)and Quercetin (50 mg/kg)monthly for 4 months by gavage
Mice C57BI/6

20 months
Vertebrae

$\uparrow$ Trabecular BV/TV, number and

thickness

$\downarrow N O c$

No difference in Ob numbers, BFR,

MAR

Femur

$\uparrow$ cortical thickness

$\uparrow$ strength

$\downarrow$ endocortical N Oc

endocortical $\mathrm{N} \mathrm{Ob}$

\begin{tabular}{|c|c|c|c|c|}
\hline $\begin{array}{l}\text { Fisetin } \\
5 \mathrm{mg} / \mathrm{kg} / \text { day or } 50 \mathrm{mg} / \mathrm{kg} / \text { day for } 1 \text { week by gavage prior to } \\
\text { OVX followed by } 5 \mathrm{mg} / \mathrm{kg} / \text { day } \\
25 \mathrm{mg} / \mathrm{kg} / \text { day for } 4 \text { weeks by gavage } \\
5 \mathrm{mg} / \mathrm{kg} / \text { day } \\
25 \mathrm{mg} / \mathrm{kg} / \text { day } 50 \mathrm{mg} / \mathrm{kg} / \text { day for } 3 \text { weeks by gavage }\end{array}$ & $\begin{array}{l}\text { Mice C57Bl/6 + OVX } \\
\text { C57Bl/6 + LPS }\end{array}$ & 8 weeks & $\begin{array}{l}\uparrow \mathrm{BMD} \\
\uparrow \text { serum OCN } \\
\uparrow \mathrm{BMD}\end{array}$ & $\begin{array}{l}\text { Léotoing et al. } \\
\text { (2013) }\end{array}$ \\
\hline $\begin{array}{l}\text { Navitoclax } \\
50 \mathrm{mg} / \mathrm{kg} / \text { day for } 2 \text { weeks by gavage }\end{array}$ & Mice C57BI/6 & 24 months & $\uparrow$ Trabecular BV/TV & $\begin{array}{l}\text { Sharma et al. } \\
(2020)\end{array}$ \\
\hline $\begin{array}{l}\text { N-Acetyl Glucosamine } \\
100 \mathrm{mg} / \mathrm{kg} / \text { day } \\
250 \mathrm{mg} / \mathrm{kg} / \text { day for } 12 \text { weeks }\end{array}$ & Sprague-Dawley Rats & 12 weeks & $\begin{array}{l}\uparrow \mathrm{BV} / \mathrm{TV} \\
\uparrow T r a b e c u l a r \text { bone area }\end{array}$ & Jiang et al. (2018) \\
\hline Spermidine 0.3-3 mM/day drinking water & C57BL6 mice + OVX & 8 weeks & $\begin{array}{l}\uparrow B V / T V \\
\downarrow N \text { Oc }\end{array}$ & $\begin{array}{l}\text { Yamamoto et al. } \\
(2012)\end{array}$ \\
\hline
\end{tabular}

SD, Sprague-Dawley; i.p, intra-peritoneal; BMD, Bone mineral density; MAR, Mineral apposition rates; BFR, Bone Formation Rates; Oc, Osteoclasts; OCN, osteocalcin; Ob, Osteoblasts; ALP, Alkaline phosphatase; LPS, lypopolysaccharide. 
Long-term studies with Rapamycin and its derivatives are required to assess its effect on osteoblastogenesis and whether both cortical and trabecular bone benefit from the intervention when exposed for prolonged periods. Careful consideration needs to be given to the dose and time of administration and the type of mTOR inhibitor as prolonged administration of Rapamycin may have side effects. Intermittent dosing has been proposed to avoid adverse events (Arriola Apelo et al., 2016). However, regimen of Rapamycin $2 \mathrm{mg} / \mathrm{kg}$ once every 5 days has been shown to inhibit mTORC1 complex but loss of glucose tolerance persisted in the same way than what was observed when given daily (Houde et al., 2010). In humans no major side effects have been seen with weekly dosing of Everolimus and this was enough to improve immune responses (Mannick et al., 2014). However, Everolimus administered at a weekly dose did not produce any difference on bone parameters (Kneissel et al., 2004), suggesting that daily dose may be required to detect effects. However, Everolimus may still be preferable to Rapamycin. Indeed when given daily it had reduced impact on glucose tolerance compared to daily Rapamycin despite being equally efficacious in inhibiting proteins of the TORC1 complex (Arriola Apelo et al., 2016).

The effect with senolytics has shown mixed results. Pharmacologic clearance of senescence cells in aged mice (20 months) treated with Dasatinib and Quercetin (DQ) for 4 months by single monthly administration showed improvement of both the trabecular and cortical bone in femur and vertebrae (Farr et al., 2017). DQ suppressed resorption by reducing osteoclast numbers and improved osteoblast numbers on the cortical bone surface but not on the trabecular bone surface (Farr et al., 2017).

When Fisetin was given to 8 weeks old mice, 1 week before OVX, an increase in trabecular bone volume fraction, thickness and number were observed 4 weeks after OVX (Léotoing et al., 2013). A similar effect was also reported when using a model of inflammation-induced bone loss by Lypopolysaccharide injection (Léotoing et al., 2013). However, it is unlikely that these effects are due to Fisetin's senolytic activity. Very low levels of senescent cells have been reported in mice before 8 months of age (Farr et al., 2017). Studies in aged mice are required to determine whether Fisetin has senolytic effects and prevent bone loss observed with age.

Detrimental effects to trabecular bone were reported in aged male and female C57BL/6 mice (24 months old), when they were treated with the senolytic drug Navitoclax once daily for 2 weeks with signs of apoptosis on bone cells (Sharma et al., 2020). The same dose was used in the study by Chang et al. (Chang et al., 2016) to eliminate senescent cells. Indeed it showed improved proliferation and regeneration ability of hematopoietic stem cells (HSC), compatible with a reversal of HSC to a more youthful phenotype (Chang et al., 2016). However, Navitoclax was administered only for 7 days in the study by Chang et al. (Chang et al., 2016) as opposed to 14 days in the study by (Sharma et al., 2020). This may account for the toxicity observed. The toxicity of Navitoclax is well known and therefore improved regimen should be tested, particularly with the new galacto-conjugated Navitoclax, where the drug can be preferentially activated by SA- $\beta$-gal activity primarily in senescent cells (González-Gualda et al., 2020).
Studies on spermidine and Glucosamine are still in their infancy and limited to young mice. Spermidine was administered at $0.3-3 \mathrm{mM} /$ day orally to 8 weeks old ovariectomised C57BL6 mice and analysed 28 days after OVX. Analysis of vertebral bone showed an increase in BV/TV associated with a decreased in the number of osteoclasts and no effects on osteoblasts (Yamamoto et al., 2012). N-Acethyl Glucosamine was administered at $250 \mathrm{mg} / \mathrm{kg}$ and $100 \mathrm{mg} / \mathrm{kg} /$ day to 12 weeks old ovarectomised Sprague-Dawley rats for 12 weeks. An increase in bone mineral density and trabecular bone area was observed. This was associated with signs of increased osteoblasts differentiation and mineralizations (Yamamoto et al., 2012). Effects on osteoclasts were no reported. Although these studies are promising, more in depth studies in aged mice are required to assess whether these agents hold promise for attenuating bone loss with age.

\section{CONCLUSION}

Geroprotectors potentially have additional benefits to treat OA and $\mathrm{OP}$ and their co-morbidities. However, few studies focus on skeletal health despite their burden of disease. Only one study with the combination of senolytics DQ shows signs of improvement in a model of bone loss and no improvement has been demonstrated so far in aged models of OA. These studies highlight that extension of lifespan cannot be considered a surrogate marker for extension of health span in all tissues and thorough studies in aged models of $\mathrm{OP}$ and $\mathrm{OA}$ are required to assess the real benefit of geroprotectors to improve skeletal health.

\section{AUTHOR CONTRIBUTIONS}

$\mathrm{AR}, \mathrm{MB}$, and JG performed the experiments, analysed the data, reviewed and approved the manuscript. ED designed the study, reviewed and approved the manuscript. MN wrote and approved the manuscript. IB designed the experiments, analysed the data, wrote and approved the manuscript.

\section{FUNDING}

This work was supported by the Biotechnology and Biological Science Research Council Grant Ref N BB/R001510/1.

\section{ACKNOWLEDGMENTS}

We are grateful to Richard Miller at the University of Michigan for donating mouse tissues from the UM-HET3 mice.

\section{SUPPLEMENTARY MATERIAL}

The Supplementary Material for this article can be found online at: https://www.frontiersin.org/articles/10.3389/fcell.2022.682045/ full\#supplementary-material 


\section{REFERENCES}

Algire, C., Moiseeva, O., Deschênes-Simard, X., Amrein, L., Petruccelli, L., Birman, E., et al. (2012). Metformin Reduces Endogenous Reactive Oxygen Species and Associated DNA Damage. Cancer Prev. Res. 5, 536-543. doi:10.1158/19406207.capr-11-0536

Aroda, V. R., Knowler, W. C., Knowler, W. C., Crandall, J. P., Perreault, L., Edelstein, S. L., et al. (2017). For the Diabetes Prevention Program ResearchMetformin for Diabetes Prevention: Insights Gained from the Diabetes Prevention Program/Diabetes Prevention Program Outcomes Study. Diabetologia 60, 1601-1611. doi:10.1007/s00125-017-4361-9

Arriola Apelo, S. I., Neuman, J. C., Baar, E. L., Syed, F. A., Cummings, N. E., Brar, H. K., et al. (2016). Alternative Rapamycin Treatment Regimens Mitigate the Impact of Rapamycin on Glucose Homeostasis and the Immune System. Aging Cell 15, 28-38. doi:10.1111/acel.12405

Ashabi, G., Khalaj, L., Khodagholi, F., Goudarzvand, M., and Sarkaki, A. (2015). Pre-treatment with Metformin Activates Nrf2 Antioxidant Pathways and Inhibits Inflammatory Responses through Induction of AMPK after Transient Global Cerebral Ischemia. Metab. Brain Dis. 30, 747-754. doi:10. 1007/s11011-014-9632-2

Barzilai, N., Crandall, J. P., Kritchevsky, S. B., and Espeland, M. A. (2016). Metformin as a Tool to Target Aging. Cel Metab. 23, 1060-1065. doi:10. 1016/j.cmet.2016.05.011

Bellantuono, I. (2018). Find Drugs that Delay many Diseases of Old Age. Nature 554, 293-295. doi:10.1038/d41586-018-01668-0

Bijlsma, J. W., Berenbaum, F., and Lafeber, F. P. (2011). Osteoarthritis: an Update with Relevance for Clinical Practice. Lancet 377, 2115-2126. doi:10.1016/s01406736(11)60243-2

Bosi, E. (2009). Metformin - the Gold Standard in Type 2 Diabetes: what Does the Evidence Tell Us? Diabetes Obes. Metab. 11, 3-8. doi:10.1111/j.1463-1326.2008. 01031.x

Browne, A. J., Kubasch, M. L., Göbel, A., Hadji, P., Chen, D., Rauner, M., et al. (2017). Concurrent Antitumor and Bone-Protective Effects of Everolimus in Osteotropic Breast Cancer. Breast Cancer Res. : BCR 19, 92. doi:10.1186/s13058017-0885-7

Burrage, P. S., Mix, K. S., and Brinckerhoff, C. E. (2006). Matrix Metalloproteinases: Role in Arthritis. Front. Biosci. 11, 529-543. doi:10. $2741 / 1817$

Caramés, B., Hasegawa, A., Taniguchi, N., Miyaki, S., Blanco, F. J., and Lotz, M. (2012a). Autophagy Activation by Rapamycin Reduces Severity of Experimental Osteoarthritis. Ann. Rheum. Dis. 71, 575-581. doi:10.1136/ annrheumdis-2011-200557

Caramés, B., Taniguchi, N., Otsuki, S., Blanco, F. J., and Lotz, M. (2010). Autophagy Is a Protective Mechanism in normal Cartilage, and its AgingRelated Loss Is Linked with Cell Death and Osteoarthritis. Arthritis Rheum. 62, 791-801. doi:10.1002/art.27305

Caramés, B., Taniguchi, N., Seino, D., Blanco, F. J., D'lima, D., and Lotz, M. (2012b). Mechanical Injury Suppresses Autophagy Regulators and Pharmacologic Activation of Autophagy Results in Chondroprotection. Arthritis Rheum. 64, 1182-1192. doi:10.1002/art.33444

Chang, J., Wang, Y., Shao, L., Laberge, R.-M., Demaria, M., Campisi, J., et al. (2016). Clearance of Senescent Cells by ABT263 Rejuvenates Aged Hematopoietic Stem Cells in Mice. Nat. Med. 22, 78-83. doi:10.1038/nm.4010

Chen, Z., Lin, C.-X., Song, B., Li, C.-C., Qiu, J.-X., Li, S.-X., et al. (2020). Spermidine Activates RIP1 Deubiquitination to Inhibit TNF- $\alpha$-Induced NF- $\mathrm{kB} / \mathrm{p} 65$ Signaling Pathway in Osteoarthritis. Cel Death Dis. 11, 503. doi:10.1038/ s41419-020-2710-y

Crandall, C. J., Newberry, S. J., Diamant, A., Lim, Y. W., Gellad, W. F., Booth, M. J., et al. (2014). Comparative Effectiveness of Pharmacologic Treatments to Prevent Fractures: an Updated Systematic Review. Ann. Intern. Med. 161, 711-723. doi:10.7326/m14-0317

D'adamo, S., Cetrullo, S., Guidotti, S., Silvestri, Y., Minguzzi, M., Santi, S., et al. (2020). Spermidine Rescues the Deregulated Autophagic Response to Oxidative Stress of Osteoarthritic Chondrocytes. Free Radic. Biol. Med. 153, 159-172. doi:10.1016/j.freeradbiomed.2020.03.029

Denzel, Martin. s., Storm, Nadia. j., Gutschmidt, A., Baddi, R., Hinze, Y., Jarosch, E., et al. (2014). Hexosamine Pathway Metabolites Enhance
Protein Quality Control and Prolong Life. Cell 156, 1167-1178. doi:10. 1016/j.cell.2014.01.061

Dinicolantonio, J. J., Bhutani, J., and O'keefe, J. H. (2015). Acarbose: Safe and Effective for Lowering Postprandial Hyperglycaemia and Improving Cardiovascular Outcomes. Open Heart 2, e000327. doi:10.1136/openhrt2015-000327

Eisenberg, T., Abdellatif, M., Schroeder, S., Primessnig, U., Stekovic, S., Pendl, T., et al. (2016). Cardioprotection and Lifespan Extension by the Natural Polyamine Spermidine. Nat. Med. 22, 1428-1438. doi:10.1038/nm.4222

Eisenberg, T., Knauer, H., Schauer, A., Büttner, S., Ruckenstuhl, C., CarmonaGutierrez, D., et al. (2009). Induction of Autophagy by Spermidine Promotes Longevity. Nat. Cel Biol. 11, 1305-1314. doi:10.1038/ncb1975

Ewart, D., Harper, L., Gravely, A., Miller, R. A., Carlson, C. S., and Loeser, R. F. (2020). Naturally Occurring Osteoarthritis in Male Mice with an Extended Lifespan. Connect. Tissue Res. 61, 95-103. doi:10.1080/03008207.2019. 1635590

Executive, L. H. A. S. (2015). Work Related Musculoskeletal Disorder Statistics (WRMSDs) in Great Britain 2014/15. [Online]. Available: https://www.england.nhs.uk/ourwork/ clinical-policy/ltc/our-work-on-long-term-conditions/musculoskeletal/.[Accessed].

Farr, J. N., and Khosla, S. (2019). Cellular Senescence in Bone. Bone 121, 121-133. doi:10.1016/j.bone.2019.01.015

Farr, J. N., Xu, M., Weivoda, M. M., Monroe, D. G., Fraser, D. G., Onken, J. L., et al. (2017). Targeting Cellular Senescence Prevents Age-Related Bone Loss in Mice. Nat. Med. 23, 1072-1079. doi:10.1038/nm.4385

Feng, X., Pan, J., Li, J., Zeng, C., Qi, W., Shao, Y., et al. (2020). Metformin Attenuates Cartilage Degeneration in an Experimental Osteoarthritis Model by Regulating AMPK/mTOR. Aging 12, 1087-1103. doi:10.18632/aging.102635

Figueira, I., Fernandes, A., Mladenovic Djordjevic, A., Lopez-Contreras, A., Henriques, C. M., Selman, C., et al. (2016). Interventions for Age-Related Diseases: Shifting the Paradigm. Mech. Ageing Dev. 160, 69-92. doi:10.1016/j. mad.2016.09.009

Futosi, K., Németh, T., Pick, R., Vántus, T., Walzog, B., and Mócsai, A. (2012). Dasatinib Inhibits Proinflammatory Functions of Mature Human Neutrophils. Blood 119, 4981-4991. doi:10.1182/blood-2011-07-369041

Garratt, M., Bower, B., Garcia, G. G., and Miller, R. A. (2017). Sex Differences in Lifespan Extension with Acarbose and 17-a Estradiol: Gonadal Hormones Underlie Male-specific Improvements in Glucose Tolerance and mTORC2 Signaling. Aging Cell 16, 1256-1266. doi:10.1111/acel.12656

Garratt, M., Leander, D., Pifer, K., Bower, B., Herrera, J. J., Day, S. M., et al. (2019). 17- $\alpha$ Estradiol Ameliorates Age-Associated Sarcopenia and Improves Late-Life Physical Function in Male Mice but Not in Females or Castrated Males. Aging Cell 18, e12920. doi:10.1111/acel.12920

Glantschnig, H., Fisher, J. E., Wesolowski, G., Rodan, G. A., and Reszka, A. A. (2003). M-CSF, TNFa and RANK Ligand Promote Osteoclast Survival by Signaling through mTOR/S6 Kinase. Cel Death Differ. 10, 1165-1177. doi:10. 1038/sj.cdd.4401285

Goldring, M. B., and Otero, M. (2011). Inflammation in Osteoarthritis. Curr. Opin. Rheumatol. 23, 471-478. doi:10.1097/bor.0b013e328349c2b1

Goldring, M. B. (2000). The Role of the Chondrocyte in Osteoarthritis. Arthritis Rheum. 43, 1916-1926. doi:10.1002/1529-0131(200009)43:9<1916:aid-anr2>3. $0 . \operatorname{co} ; 2-\mathrm{i}$

González-Gualda, E., Pàez-Ribes, M., Lozano-Torres, B., Macias, D., Wilson, J. R., 3rd, González-López, C., et al. (2020). Galacto-conjugation of Navitoclax as an Efficient Strategy to Increase Senolytic Specificity and Reduce Platelet Toxicity. Aging cell 19, e13142.

Grishko, V. I., Ho, R., Wilson, G. L., and Pearsall, A. W. T. (2009). Diminished Mitochondrial DNA Integrity and Repair Capacity in OA Chondrocytes. Osteoarthritis Cartilage 17, 107-113. doi:10.1016/j.joca.2008.05.009

Harrison, D. E., Strong, R., Alavez, S., Astle, C. M., Digiovanni, J., Fernandez, E., et al. (2019). Acarbose Improves Health and Lifespan in Aging HET3 Mice. Aging Cell 18, e12898. doi:10.1111/acel.12898

Harrison, D. E., Strong, R., Allison, D. B., Ames, B. N., Astle, C. M., Atamna, H., et al. (2014). Acarbose, 17- $\alpha$-Estradiol, and Nordihydroguaiaretic Acid Extend Mouse Lifespan Preferentially in Males. Aging Cell 13, 273-282. doi:10.1111/ acel.12170

Harrison, D. E., Strong, R., Sharp, Z. D., Nelson, J. F., Astle, C. M., Flurkey, K., et al. (2009). Rapamycin Fed Late in Life Extends Lifespan in Genetically Heterogeneous Mice. Nature 460, 392-395. doi:10.1038/nature08221 
Health and Safety Executive (2020). Health and Safety at Work. Summary Statistics for Great Britain 2020. [Online]. Available: https://www.hse.gov.uk/statistics/ overall/hssh1920.pdf.[Accessed].

Henrotin, Y., Mobasheri, A., and Marty, M. (2012). Is There Any Scientific Evidence for the Use of Glucosamine in the Management of Human Osteoarthritis? Arthritis Res. Ther. 14, 201. doi:10.1186/ar3657

Herrera, J. J., Louzon, S., Pifer, K., Leander, D., Merrihew, G. E., Park, J. H., et al. (2020). Acarbose Has Sex-dependent and -independent Effects on Age-Related Physical Function, Cardiac Health, and Lipid Biology. JCI Insight 5, 1573-1589. doi:10.1172/jci.insight.137474

Houde, V. P., Brûlé, S., Festuccia, W. T., Blanchard, P.-G., Bellmann, K., Deshaies, Y., et al. (2010). Chronic Rapamycin Treatment Causes Glucose Intolerance and Hyperlipidemia by Upregulating Hepatic Gluconeogenesis and Impairing Lipid Deposition in Adipose Tissue. Diabetes 59, 1338-1348. doi:10.2337/db091324

Huang, B., Wang, Y., Wang, W., Chen, J., Lai, P., Liu, Z., et al. (2015). mTORC1 Prevents Preosteoblast Differentiation through the Notch Signaling Pathway. PLOS Genet. 11, e1005426. doi:10.1371/journal.pgen.1005426

Huang, H., Skelly, J. D., Ayers, D. C., and Song, J. (2017). Age-dependent Changes in the Articular Cartilage and Subchondral Bone of C57BL/6 Mice after Surgical Destabilization of Medial Meniscus. Sci. Rep. 7, 42294. doi:10. $1038 /$ srep 42294

Inc, U. B. (2020). UNITY Biotechnology Announces 12-week Data from UBX0101 Phase 2 Clinical Study in Patients with Painful Osteoarthritis of the Knee. [Online]. Available: https://www.globenewswire.com/news-release/2020/08/ 17/2079116/0/en/UNITY-Biotechnology-Announces-12-week-data-fromUBX0101-Phase-2-Clinical-Study-in-Patients-with-Painful-Osteoarthritis-ofthe-Knee.html.[Accessed]

Jänne, J., Raina, A., and Siimes, M. (1964). Spermidine and Spermine in Rat Tissues at Different Ages. Acta Physiol. Scand. 62, 352-358.

Jeon, O. H., Kim, C., Laberge, R.-M., Demaria, M., Rathod, S., Vasserot, A. P., et al. (2017). Local Clearance of Senescent Cells Attenuates the Development of posttraumatic Osteoarthritis and Creates a Pro-regenerative Environment. Nat. Med. 23, 775-781. doi:10.1038/nm.4324

Jeyapalan, J. C., Ferreira, M., Sedivy, J. M., and Herbig, U. (2007). Accumulation of Senescent Cells in Mitotic Tissue of Aging Primates. Mech. Ageing Development 128, 36-44. doi:10.1016/j.mad.2006.11.008

Jiang, Z., Li, Z., Zhang, W., Yang, Y., Han, B., Liu, W., et al. (2018). Dietary Natural N-Acetyl-D-Glucosamine Prevents Bone Loss in Ovariectomized Rat Model of Postmenopausal Osteoporosis. Molecules (Basel, Switzerland) 23, 2302. doi:10. 3390/molecules 23092302

Johnson, S. C., Rabinovitch, P. S., and Kaeberlein, M. (2013). mTOR Is a Key Modulator of Ageing and Age-Related Disease. Nature 493, 338-345. doi:10. 1038/nature11861

Kadam, U. T., Jordan, K., and Croft, P. R. (2004). Clinical Comorbidity in Patients with Osteoarthritis: a Case-Control Study of General Practice Consulters in England and Wales. Ann. Rheum. Dis. 63, 408-414. doi:10.1136/ard.2003. 007526

Kiechl, S., Pechlaner, R., Willeit, P., Notdurfter, M., Paulweber, B., Willeit, K., et al. (2018). Higher Spermidine Intake Is Linked to Lower Mortality: a Prospective Population-Based Study. Am. J. Clin. Nutr. 108, 371-380. doi:10.1093/ajcn/ nqy102

Kirkland, J. L., and Tchkonia, T. (2020). Senolytic Drugs: from Discovery to Translation. J. Intern. Med. 288, 518-536. doi:10.1111/joim.13141

Kirkland, J. L., Tchkonia, T., Zhu, Y., Niedernhofer, L. J., and Robbins, P. D. (2017). The Clinical Potential of Senolytic Drugs. J. Am. Geriatr. Soc. 65, 2297-2301. doi:10.1111/jgs.14969

Kneissel, M., Luong-Nguyen, N. H., Baptist, M., Cortesi, R., Zumstein-Mecker, S., Kossida, S., et al. (2004). Everolimus Suppresses Cancellous Bone Loss, Bone Resorption, and Cathepsin K Expression by Osteoclasts. Bone 35, 1144-1156. doi:10.1016/j.bone.2004.07.013

Kulkarni, A. S., Gubbi, S., and Barzilai, N. (2020). Benefits of Metformin in Attenuating the Hallmarks of Aging. Cel Metab. 32, 15-30. doi:10.1016/j.cmet. 2020.04.001

Léotoing, L., Wauquier, F., Guicheux, J., Miot-Noirault, E., Wittrant, Y., and Coxam, V. (2013). The Polyphenol Fisetin Protects Bone by Repressing NF-Kb and MKP-1-dependent Signaling Pathways in Osteoclasts. PLoS One 8, e68388. doi:10.1371/journal.pone.0068388
Li, H., Ding, X., Terkeltaub, R., Lin, H., Zhang, Y., Zhou, B., et al. (2020a). Exploration of Metformin as Novel Therapy for Osteoarthritis: Preventing Cartilage Degeneration and Reducing Pain Behavior. Arthritis Res. Ther. 22, 34. doi:10.1186/s13075-020-2129-y

Li, J., Kim, S. G., and Blenis, J. (2014). Rapamycin: One Drug, many Effects. Cell Metab 19, 373-379. doi:10.1016/j.cmet.2014.01.001

Li, J., Zhang, B., Liu, W.-X., Lu, K., Pan, H., Wang, T., et al. (2020b). Metformin Limits Osteoarthritis Development and Progression through Activation of AMPK Signalling. Ann. Rheum. Dis. 79, 635-645. doi:10.1136/annrheumdis2019-216713

Li, Z.-H., Gao, X., Chung, V. C., Zhong, W.-F., Fu, Q., Lv, Y.-B., et al. (2020c). Associations of Regular Glucosamine Use with All-Cause and Cause-specific Mortality: a Large Prospective Cohort Study. Ann. Rheum. Dis. 79, 829-836. doi:10.1136/annrheumdis-2020-217176

Liu, X., Machado, G. C., Eyles, J. P., Ravi, V., and Hunter, D. J. (2018). Dietary Supplements for Treating Osteoarthritis: a Systematic Review and MetaAnalysis. Br. J. Sports Med. 52, 167-175. doi:10.1136/bjsports-2016-097333

Loeser, R. F., Carlson, C. S., Del Carlo, M., and Cole, A. (2002). Detection of Nitrotyrosine in Aging and Osteoarthritic Cartilage: Correlation of Oxidative Damage with the Presence of Interleukin-1beta and with Chondrocyte Resistance to Insulin-like Growth Factor 1. Arthritis Rheum. 46, 2349-2357. doi:10.1002/art.10496

Loeser, R. F., Collins, J. A., and Diekman, B. O. (2016). Ageing and the Pathogenesis of Osteoarthritis. Nat. Rev. Rheumatol. 12, 412-420. doi:10. 1038/nrrheum.2016.65

Lotz, M. K., and Caramés, B. (2011). Autophagy and Cartilage Homeostasis Mechanisms in Joint Health, Aging and OA. Nat. Rev. Rheumatol. 7, 579-587. doi:10.1038/nrrheum.2011.109

Luo, D., Ren, H., Li, T., Lian, K., and Lin, D. (2016). Rapamycin Reduces Severity of Senile Osteoporosis by Activating Osteocyte Autophagy. Osteoporos. Int. 27, 1093-1101. doi:10.1007/s00198-015-3325-5

Ma, H., Li, X., Sun, D., Zhou, T., Ley, S. H., Gustat, J., et al. (2019). Association of Habitual Glucosamine Use with Risk of Cardiovascular Disease: Prospective Study in UK Biobank. BMJ 365, 11628. doi:10.1136/bmj.11628

Maglione, M., Kochlamazashvili, G., Eisenberg, T., Rácz, B., Michael, E., Toppe, D., et al. (2019). Spermidine Protects from Age-Related Synaptic Alterations at Hippocampal Mossy fiber-CA3 Synapses. Scientific Rep. 9, 19616. doi:10.1038/ s41598-019-56133-3

Mannick, J. B., Del Giudice, G., Lattanzi, M., Valiante, N. M., Praestgaard, J., Huang, B., et al. (2014). mTOR Inhibition Improves Immune Function in the Elderly. Sci. Translational Med. 6, 268ra179. doi:10.1126/scitranslmed.3009892

Mannick, J. B., Morris, M., Hockey, H.-U. P., Roma, G., Beibel, M., Kulmatycki, K., et al. (2018). TORC1 Inhibition Enhances Immune Function and Reduces Infections in the Elderly. Sci. Translational Med. 10, eaaq1564. doi:10.1126/ scitranslmed.aaq1564

Manolagas, S. C. (2000). Birth and Death of Bone Cells: Basic Regulatory Mechanisms and Implications for the Pathogenesis and Treatment of Osteoporosis. Endocr. Rev. 21, 115-137. doi:10.1210/er.21.2.115

Matsuzaki, T., Matsushita, T., Tabata, Y., Saito, T., Matsumoto, T., Nagai, K., et al. (2014). Intra-articular Administration of Gelatin Hydrogels Incorporating Rapamycin-Micelles Reduces the Development of Experimental Osteoarthritis in a Murine Model. Biomaterials 35, 9904-9911. doi:10.1016/ j.biomaterials.2014.08.041

Mccarty, M. F., O'keefe, J. H., and Dinicolantonio, J. J. (2019). Glucosamine for the Treatment of Osteoarthritis: The Time Has Come for Higher-Dose Trials. J. Diet. Suppl. 16, 179-192. doi:10.1080/19390211.2018.1448920

Miller, R. A., Harrison, D. E., Astle, C. M., Baur, J. A., Boyd, A. R., De Cabo, R., et al. (2011). Rapamycin, but Not Resveratrol or Simvastatin, Extends Life Span of Genetically Heterogeneous Mice. J. Gerontol. A. Biol. Sci. Med. Sci. 66, 191-201. doi:10.1093/gerona/glq178

Miller, R. A., Harrison, D. E., Astle, C. M., Fernandez, E., Flurkey, K., Han, M., et al. (2014). Rapamycin-mediated Lifespan Increase in Mice Is Dose and Sex Dependent and Metabolically Distinct from Dietary Restriction. Aging Cell 13, 468-477. doi:10.1111/acel.12194

Moiseeva, O., Deschênes-Simard, X., St-Germain, E., Igelmann, S., Huot, G., Cadar, A. E., et al. (2013). Metformin Inhibits the Senescence-Associated Secretory Phenotype by Interfering with IKK/NF-кB Activation. Aging Cell 12, 489-498. doi:10.1111/acel.12075 
Morsli, S., and Bellantuono, I. (2021). The Use of Geroprotectors to Prevent Multimorbidity: Opportunities and Challenges. Mech. Ageing Dev. 193, 111391. doi:10.1016/j.mad.2020.111391

Nadon, N. L., Strong, R., Miller, R. A., and Harrison, D. E. (2017). NIA Interventions Testing Program: Investigating Putative Aging Intervention Agents in a Genetically Heterogeneous Mouse Model. EBioMedicine 21, 3-4. doi:10.1016/j.ebiom.2016.11.038

Naito, K., Watari, T., Furuhata, A., Yomogida, S., Sakamoto, K., Kurosawa, H., et al. (2010). Evaluation of the Effect of Glucosamine on an Experimental Rat Osteoarthritis Model. Life Sci. 86, 538-543. doi:10.1016/j.lfs.2010. 02.015

Nelson, J. F., Felicio, L. S., Randall, P. K., Sims, C., and Finch, C. E. (1982). A Longitudinal Study of Estrous Cyclicity in Aging C57BL/6J Mice: I. Cycle Frequency, Length and Vaginal Cytology. Biol. Reprod. 27, 327-339. doi:10. 1095/biolreprod27.2.327

Noro, T., Namekata, K., Kimura, A., Guo, X., Azuchi, Y., Harada, C., et al. (2015). Spermidine Promotes Retinal Ganglion Cell Survival and Optic Nerve Regeneration in Adult Mice Following Optic Nerve Injury. Cel Death Dis. 6, e1720. doi:10.1038/cddis.2015.93

Ogata, T., Ideno, Y., Akai, M., Seichi, A., Hagino, H., Iwaya, T., et al. (2018). Effects of Glucosamine in Patients with Osteoarthritis of the Knee: a Systematic Review and Meta-Analysis. Clin. Rheumatol. 37, 2479-2487. doi:10.1007/s10067-018$4106-2$

Owens, S., Wagner, P., and Vangsness, C. T., Jr. (2004). Recent Advances in Glucosamine and Chondroitin Supplementation. J. Knee Surg. 17, 185-193. doi:10.1055/s-0030-1248220

Pal, B., Endisha, H., Zhang, Y., and Kapoor, M. (2015). mTOR: a Potential Therapeutic Target in Osteoarthritis? Drugs in R\&D 15, 27-36. doi:10.1007/ s40268-015-0082-z

Partridge, L., Fuentealba, M., and Kennedy, B. K. (2020). The Quest to Slow Ageing through Drug Discovery. Nat. Rev. Drug Discov. 19, 513-532. doi:10.1038/ s41573-020-0067-7

Pignolo, R. J., Samsonraj, R. M., Law, S. F., Wang, H., and Chandra, A. (2019). Targeting Cell Senescence for the Treatment of Age-Related Bone Loss. Curr. Osteoporos. Rep. 17, 70-85. doi:10.1007/s11914-019-00504-2

Poole, K. E., and Compston, J. E. (2006). Osteoporosis and its Management. Bmj 333, 1251-1256. doi:10.1136/bmj.39050.597350.47

Raud, B., Gay, C., Guiguet-Auclair, C., Bonnin, A., Gerbaud, L., Pereira, B., et al. (2020). Level of Obesity Is Directly Associated with the Clinical and Functional Consequences of Knee Osteoarthritis. Scientific Rep. 10, 3601. doi:10.1038/ s41598-020-60587-1

Riggs, B. L., Melton, L. J., Robb, R. A., Camp, J. J., Atkinson, E. J., Mcdaniel, L., et al. (2008). A Population-Based Assessment of Rates of Bone Loss at Multiple Skeletal Sites: Evidence for Substantial Trabecular Bone Loss in Young Adult Women and Men. J. Bone Miner Res. 23, 205-214. doi:10. 1359/jbmr.071020

Rodriguez, G. H., Ahmed, S. I., Al-Akhrass, F., Rallapalli, V., and Safdar, A. (2012). Characteristics of, and Risk Factors for, Infections in Patients with Cancer Treated with Dasatinib and a Brief Review of Other Complications. Leuk. Lymphoma 53, 1530-1535. doi:10.3109/10428194.2012.656626

Rothwell, A. G., and Bentley, G. (1973). Chondrocyte Multiplication in Osteoarthritic Articular Cartilage. J. Bone Jt. Surg Br 55, 588-594. doi:10. 1302/0301-620x.55b3.588

Runhaar, J., Rozendaal, R. M., Van Middelkoop, M., Bijlsma, H. J. W., Doherty, M., Dziedzic, K. S., et al. (2017). Subgroup Analyses of the Effectiveness of Oral Glucosamine for Knee and Hip Osteoarthritis: a Systematic Review and Individual Patient Data Meta-Analysis from the OA Trial Bank. Ann. Rheum. Dis. 76, 1862-1869. doi:10.1136/annrheumdis-2017-211149

Salive, M. E. (2013). Multimorbidity in Older Adults. Epidemiologic Rev. 35, 75-83. doi:10.1093/epirev/mxs009

Saxton, R. A., and Sabatini, D. M. (2017). mTOR Signaling in Growth, Metabolism, and Disease. Cell 168, 960-976. doi:10.1016/j.cell.2017.02.004

Sharma, A. K., Roberts, R. L., Benson, R. D., Jr., Pierce, J. L., Yu, K., Hamrick, M. W., et al. (2020). The Senolytic Drug Navitoclax (ABT-263) Causes Trabecular Bone Loss and Impaired Osteoprogenitor Function in Aged Mice. Front. Cel. Dev. Biol. 8, 354. doi:10.3389/fcell.2020.00354

Silvestri, Y., D’adamo, S., Cetrullo, S., Minguzzi, M., Guidotti, S., Filardo, G., et al. (2018). Chondroprotective and Anti-oxidant Activity of Spermidine in Human
Chondrocytes. Osteoarthritis and Cartilage 26, S343. doi:10.1016/j.joca.2018. 02.682

Simental-Mendía, M., Sánchez-García, A., Vilchez-Cavazos, F., Acosta-Olivo, C. A., Peña-Martínez, V. M., and Simental-Mendía, L. E. (2018). Effect of Glucosamine and Chondroitin Sulfate in Symptomatic Knee Osteoarthritis: a Systematic Review and Meta-Analysis of Randomized Placebo-Controlled Trials. Rheumatol. Int. 38, 1413-1428.

Singha, U. K., Jiang, Y., Yu, S., Luo, M., Lu, Y., Zhang, J., et al. (2008). Rapamycin Inhibits Osteoblast Proliferation and Differentiation in MC3T3-E1 Cells and Primary Mouse Bone Marrow Stromal Cells. J. Cel Biochem 103, 434-446. doi:10.1002/jcb.21411

Stout, M. B., Steyn, F. J., Jurczak, M. J., Camporez, J.-P. G., Zhu, Y., Hawse, J. R., et al. (2017). 17 $\alpha$-Estradiol Alleviates Age-Related Metabolic and Inflammatory Dysfunction in Male Mice without Inducing Feminization. Journals Gerontology. Ser. A, Biol. Sci. Med. Sci. 72, 3-15. doi:10.1093/gerona/glv309

Stout, M. B., Steyn, F. J., Jurczak, M. J., Camporez, J. G., Zhu, Y., Hawse, J. R., et al. (2016). 17alpha-Estradiol Alleviates Age-Related Metabolic and Inflammatory Dysfunction in Male Mice without Inducing Feminization. J. Gerontol. A. Biol. Sci. Med. Sci. 72 (1), 3-15. doi:10.1093/gerona/glv309

Strong, R., Miller, R. A., Antebi, A., Astle, C. M., Bogue, M., Denzel, M. S., et al. (2016). Longer Lifespan in Male Mice Treated with a Weakly Estrogenic Agonist, an Antioxidant, an a-glucosidase Inhibitor or a Nrf2-Inducer. Aging Cell 15, 872-884. doi:10.1111/acel.12496

Stubbs, T. M., Bonder, M. J., Stark, A.-K., Krueger, F., Bolland, D., Butcher, G., et al. (2017). Multi-tissue DNA Methylation Age Predictor in Mouse. Genome Biol. 18, 68. doi:10.1186/s13059-017-1203-5

Takayama, K., Kawakami, Y., Kobayashi, M., Greco, N., Cummins, J. H., Matsushita, T., et al. (2014). Local Intra-articular Injection of Rapamycin Delays Articular Cartilage Degeneration in a Murine Model of Osteoarthritis. Arthritis Res. Ther. 16, 482. doi:10.1186/s13075-014-0482-4

Tinetti, M. E., Fried, T. R., and Boyd, C. M. (2012). Designing Health Care for the Most Common Chronic Condition-Mmultimorbidity. Jama 307, 2493-2494. doi:10.1001/jama.2012.5265

Towheed, T., Maxwell, L., Anastassiades, T. P., Shea, B., Houpt, J. B., Welch, V., et al. (2005). Glucosamine Therapy for Treating Osteoarthritis. Cochrane Database Syst. Rev. 2005 (2), CD002946. doi:10.1002/14651858.CD002946. pub2

Valencia, W. M., Palacio, A., Tamariz, L., and Florez, H. (2017). Metformin and Ageing: Improving Ageing Outcomes beyond Glycaemic Control. Diabetologia 60, 1630-1638. doi:10.1007/s00125-017-4349-5

Van Der Heide, I., Snoeijs, S., Quattrini, S., Struckmann, V., Hujala, A., Schellevis, F., et al. (2018). Patient-centeredness of Integrated Care Programs for People with Multimorbidity. Results from the European ICARE4EU Project. Health Policy 122, 36-43. doi:10.1016/j.healthpol.2017.10.005

Vlad, S. C., Lavalley, M. P., Mcalindon, T. E., and Felson, D. T. (2007). Glucosamine for Pain in Osteoarthritis: Why Do Trial Results Differ? Arthritis Rheum. 56, 2267-2277. doi:10.1002/art.22728

Wandel, S., Jüni, P., Tendal, B., Nüesch, E., Villiger, P. M., Welton, N. J., et al. (2010). Effects of Glucosamine, Chondroitin, or Placebo in Patients with Osteoarthritis of Hip or Knee: Network Meta-Analysis. BMJ 341, c4675. doi:10.1136/bmj.c4675

Wang, C., Jurk, D., Maddick, M., Nelson, G., Martin-Ruiz, C., and Von Zglinicki, T. (2009). DNA Damage Response and Cellular Senescence in Tissues of Aging Mice. Aging Cell 8, 311-323. doi:10.1111/j.1474-9726.2009.00481.x

Wang, R., Yu, Z., Sunchu, B., Shoaf, J., Dang, I., Zhao, S., et al. (2017). Rapamycin Inhibits the Secretory Phenotype of Senescent Cells by a Nrf2-independent Mechanism. Aging Cell 16, 564-574. doi:10.1111/acel.12587

Weimer, S., Priebs, J., Kuhlow, D., Groth, M., Priebe, S., Mansfeld, J., et al. (2014). D-glucosamine Supplementation Extends Life Span of Nematodes and of Ageing Mice. Nat. Commun. 5, 3563. doi:10.1038/ncomms 4563

Wen, Z. H., Tang, C. C., Chang, Y. C., Huang, S. Y., Hsieh, S. P., Lee, C. H., et al. (2010). Glucosamine Sulfate Reduces Experimental Osteoarthritis and Nociception in Rats: Association with Changes of Mitogen-Activated Protein Kinase in Chondrocytes. Osteoarthritis Cartilage 18, 1192-1202. doi:10.1016/j.joca.2010.05.012

Wilson, W. H., O'connor, O. A., Czuczman, M. S., Lacasce, A. S., Gerecitano, J. F., Leonard, J. P., et al. (2010). Navitoclax, a Targeted High-Affinity Inhibitor of BCL-2, in Lymphoid Malignancies: a Phase 1 Dose-Escalation Study of Safety, 
Pharmacokinetics, Pharmacodynamics, and Antitumour Activity. Lancet Oncol. 11, 1149-1159. doi:10.1016/s1470-2045(10)70261-8

Woolf, A. D., and Pfleger, B. (2003). Burden of Major Musculoskeletal Conditions. Bull. World Health Organ. 81, 646-656.

Wu, J., Wang, A., Wang, X., Li, G., Jia, P., Shen, G., et al. (2019). Rapamycin Improves Bone Mass in High-Turnover Osteoporosis with Iron Accumulation through Positive Effects on Osteogenesis and Angiogenesis. Bone 121, 16-28. doi:10.1016/j.bone.2018.12.019

Xian, L., Wu, X., Pang, L., Lou, M., Rosen, C. J., Qiu, T., et al. (2012). Matrix IGF-1 Maintains Bone Mass by Activation of mTOR in Mesenchymal Stem Cells. Nat. Med. 18, 1095-1101. doi:10.1038/nm.2793

Yamamoto, T., Hinoi, E., Fujita, H., Iezaki, T., Takahata, Y., Takamori, M., et al. (2012). The Natural Polyamines Spermidine and Spermine Prevent Bone Loss through Preferential Disruption of Osteoclastic Activation in Ovariectomized Mice. Br. J. Pharmacol. 166, 1084-1096. doi:10.1111/j.1476-5381.2012.01856.x

Yang, H., Chen, C., Chen, H., Duan, X., Li, J., Zhou, Y., et al. (2020). Navitoclax (ABT263) Reduces Inflammation and Promotes Chondrogenic Phenotype by Clearing Senescent Osteoarthritic Chondrocytes in Osteoarthritis. Aging 12, 12750-12770. doi:10.18632/aging.103177

Yang, Y., Zheng, X., Li, B., Jiang, S., and Jiang, L. (2014). Increased Activity of Osteocyte Autophagy in Ovariectomized Rats and its Correlation with Oxidative Stress Status and Bone Loss. Biochem. Biophys. Res. Commun. 451, 86-92. doi:10.1016/j.bbrc.2014.07.069

Yin, X., Zhou, C., Li, J., Liu, R., Shi, B., Yuan, Q., et al. (2019). Autophagy in Bone Homeostasis and the Onset of Osteoporosis. Bone Res. 7, 28. doi:10.1038/ s41413-019-0058-7

Yue, F., Li, W., Zou, J., Jiang, X., Xu, G., Huang, H., et al. (2017). Spermidine Prolongs Lifespan and Prevents Liver Fibrosis and Hepatocellular Carcinoma by Activating MAP1S-Mediated Autophagy. Cancer Res. 77, 2938-2951. doi:10. 1158/0008-5472.can-16-3462

Zeng, C., Wei, J., Li, H., Wang, Y.-L., Xie, D.-X., Yang, T., et al. (2015). Effectiveness and Safety of Glucosamine, Chondroitin, the Two in Combination, or Celecoxib in the Treatment of Osteoarthritis of the Knee. Scientific Rep. 5, 16827. doi:10.1038/srep16827

Zhang, H., Alsaleh, G., Feltham, J., Sun, Y., Napolitano, G., Riffelmacher, T., et al. (2019). Polyamines Control eIF5A Hypusination, TFEB Translation, and Autophagy to Reverse B Cell Senescence. Mol. Cel 76, 110-125. doi:10.1016/j.molcel.2019.08.005
Zhang, Y., and Jordan, J. M. (2010). Epidemiology of Osteoarthritis. Clin. Geriatr. Med. 26, 355-369. doi:10.1016/j.cger.2010.03.001

Zhang, Y., Vasheghani, F., Li, Y.-H., Blati, M., Simeone, K., Fahmi, H., et al. (2015). Cartilage-specific Deletion of mTOR Upregulates Autophagy and Protects Mice from Osteoarthritis. Ann. Rheum. Dis. 74, 1432-1440. doi:10.1136/ annrheumdis-2013-204599

Zheng, W., Feng, Z., You, S., Zhang, H., Tao, Z., Wang, Q., et al. (2017). Fisetin Inhibits IL- $1 \beta$-induced Inflammatory Response in Human Osteoarthritis Chondrocytes through Activating SIRT1 and Attenuates the Progression of Osteoarthritis in Mice. Int. Immunopharmacol 45, 135-147. doi:10.1016/j. intimp.2017.02.009

Zhu, X., Sang, L., Wu, D., Rong, J., and Jiang, L. (2018). Effectiveness and Safety of Glucosamine and Chondroitin for the Treatment of Osteoarthritis: a MetaAnalysis of Randomized Controlled Trials. J. orthopaedic Surg. Res. 13, 170. doi:10.1186/s13018-018-0871-5

Zhu, Y., Tchkonia, T., Pirtskhalava, T., Gower, A. C., Ding, H., Giorgadze, N., et al. (2015). The Achilles' Heel of Senescent Cells: from Transcriptome to Senolytic Drugs. Aging Cell 14, 644-658. doi:10.1111/acel.12344

Conflict of Interest: The authors declare that the research was conducted in the absence of any commercial or financial relationships that could be construed as a potential conflict of interest.

Publisher's Note: All claims expressed in this article are solely those of the authors and do not necessarily represent those of their affiliated organizations, or those of the publisher, the editors and the reviewers. Any product that may be evaluated in this article, or claim that may be made by its manufacturer, is not guaranteed or endorsed by the publisher.

Copyright (c) 2022 Rayson, Boudiffa, Naveed, Griffin, Dall'Ara and Bellantuono. This is an open-access article distributed under the terms of the Creative Commons Attribution License (CC BY). The use, distribution or reproduction in other forums is permitted, provided the original author(s) and the copyright owner(s) are credited and that the original publication in this journal is cited, in accordance with accepted academic practice. No use, distribution or reproduction is permitted which does not comply with these terms. 